\title{
Will the Adoption of Clawback Provisions Mitigate Earnings Management?
}

\author{
Bradley W. Benson \\ Ball State University \\ C.S. Agnes Cheng \\ Hong Kong Polytechnic University \\ Cathy Zishang Liu \\ University of Houston Downtown
}

This paper examines the effects of voluntary adoption of clawback provisions on earnings quality. Our findings suggest neither a voluntary disincentive mechanism (clawback provisions) nor an enhanced monitoring mechanism (independent boards) can completely eliminate managers' rent extraction behaviors, in isolation. Yet, when they are coupled together, the results are the best. Specifically, a more independent board increases the likelihood of voluntary adoption of clawback provisions. The board independence also ensures improvement of earnings quality post the voluntary adoption. No such results can be observed with a less independent board. Our study provides the insights whether corporate executives can be sanctioned at firm-level by discretions of the board of directors.

\section{INTRODUCTION}

We examine the effects of voluntary adoption of clawback provisions on mitigating earnings management prior to the enactment of the Dodd-Frank Wall Street Reform and Consumer Protection Act in 2010. We focus on investigating the role of firm-level board's discretions in disciplining management's misbehaviors. In the wake of high-profile financial reporting scandals during the last decade and the recent credit market crisis, regulators, investors, and academicians continue to seek more effective corporate governance mechanisms to combat managers' rent-seeking behaviors. Clawback provisions are a promising tool for the board of directors because they empower the latter to recoup excess compensation and windfall profit gained as a result of erroneous financial information. Clawback provisions thus deter executives from engaging into manipulating earnings and financial frauds ex-ante by penalizing them for doing so ex-post (Dehaan, et. al., 2011).

Clawback provisions are not a new development. Section 304 of the Sarbanes-Oxley Act of 2002 (SOX) provides authority to the Securities and Exchange Commission (SEC) to recover ("clawback") any bonus or other incentive-based or equity-based compensations, as well as profits received from the sale of securities, from CEOs and CFOs in the year after a financial restatement, even if the executives were not involved in the violations. However, though the passage of SOX significantly enhanced corporate governance mechanisms in terms of incentive payment, board structure, and managerial accountabilities in financial reporting, (Linck, et. al., 2008; Cohen, et. al., 2007; Wang, et. al., 2010; Bargeron, et. al., 
2010), the enforcement under SOX section 304 has been sparse and inconsistent subsequent to its passage, ${ }^{1}$ even though financial restatements had increased surrounding the same period. ${ }^{2}$ There are several possible reasons. First, the SEC is the only authorized party under SOX section 304 which could legitimately "clawback" any erroneous gains from corporate executives. The SEC has limited resources and is able to only seek to recover a limited number of cases (Fried and Shilon, 2011). Further, it may take years for the SEC to file charges (Salehi and Marino, 2008). Second, without such a legal authority as the SEC does, firms and investors remain almost powerless to deal with unjustified executive pay. To a large extent, the existing executive compensation contracts and other labor laws protect executives pay, even it is erroneous or unjustified. Therefore, "very, very rarely - as in almost never", executives of financial restatement firms disgorged their "ill-earned" pay (Glater, 2005). In this sense, the SOX section 304 fails to achieve its deterrent effect to improve financial reporting quality.

A proposed adjustment to the SOX section 304 is to shift the responsibility of enforcement and interpretation of clawback provisions from the SEC to the board of directors (Cook, 2010), which could customize and carry on the provisions on firm-specific basis, allowing flexibility to address unique corporate governance problems a firm is facing. The entitlement of a disincentive scheme to the board as a new corporate governance weapon presumably helps it better play its monitoring role in curbing rentextracting behaviors, and likely, more financial reporting frauds will be preempted than under the Sox section 304 regime (Dyck, et. al., 2010). The shift towards firm-specific clawback provisions is also supported by regulators. President Obama signed the Dodd-Frank Wall Street Reform and Consumer Protection Act (the "Dodd-Frank Act") into law on July 21, 2010, ${ }^{3}$ empowering private parties to sanction their executives and seek remedies within the legal system. The Dodd-Frank Act mandates that all publicly traded companies adopt policies requiring executives to disgorge any ill-gotten gains from misreported financials. ${ }^{4}$ Again, the responsibility for designation, interpretation, and enforcement of firmspecific clawbacks falls primarily on discretions of the board of directors, and more specifically the compensation committee. ${ }^{5}$

However, whether the board of directors is also part of the corporate governance problem, contributing to excessive executive pay and internal control failure, remains a source of debates. Drawing from managerial power theory, many scholars suggest there is a variety of financial, social, and psychological reasons why directors cannot be counted on to enforce pay-for-performance provisions in executive compensation arrangements (Bebchuk, et. al., 2002; Bebchuk and Fried, 2003; Bebchuk and Fried, 2005; Fried and Shilon, 2011). The new regulation thus raises important questions with respect to whether the board of directors can be relied on to penalize misbehaving executives, when given discretions, as well as what factors will assist the board to effectively sanction their executives at firmlevel. Nonetheless, while legislators are making efforts to finalize the mandatory clawback provisions via Dodd-Frank Act, numerous companies have already chosen to voluntarily adopt firm-specific clawback provisions in the past several years. From 2006 to 2010, the number of Fortune 100 firms which publically disclosed firm-specific clawback provisions increased from $17.6 \%$ to $82.1 \%$ (Equilar, 2010).

A large body of research is devoted to understanding the role of independent boards in corporate governance (e.g., Song et. al., 2010; Hoitash, et. al., 2009; Nguyen and Nielsen, 2010; Duchin, et. al., 2010; Laux and Laux, 2009; Laux, 2007; Drymiotes, 2007). A logical extension of this line of research is whether the board independence will influence the adoption and effectiveness of voluntary clawback provisions. Research also supports the finding that the number of outsiders serving on the board increased substantially subsequently to the passage of the SOX (e.g., Burks, 2010; Collins et. al., 2009; Laux 2007; Wang, 2010; Linck, et. al., 2008; Cohen, et. al., 2007; Bargeron, et. al., 2010). However, post-SOX managerial rent seeking behaviors continuously exist. For instance, the Government Accountability Office (GAO) reports the number of financial restatements during 2002-2006 almost doubled relative to those of 1997-2001. ${ }^{6}$ Thus, an independent board may not completely eliminate managerial rent extraction by itself. The extant literature has mainly concentrated on the determinants and benefits of independent boards or clawback provisions in isolation. Little is known about the incremental effects of stronger boards and clawback provisions when they are combined. This paper attempts to fill this gap in the literature. 
We conjecture the board actively seek additional disciplinary tools to deal with earnings management since the SOX. If a disincentive mechanism such as clawback provisions emerges as a promising tool, we expect a more independent board will more likely to adopt it and this relation will be stronger for firms with high levels of earnings management prior to the such a disincentive mechanism in place. Moreover, if clawback provisions have an incremental effect in the presence of an independent board on mitigating earnings management, we expect earnings management will be reduced post adoption.

Our sample consists of 253 S\&P 1500 firms that adopt clawback provisions from 2001 to 2009 (primarily between 2006 and 2009). Consistent with our predictions, we find firms with an independent board and relatively high level of earnings management prior to the adoption are more likely to voluntarily adopt clawback provisions after controlling other corporate governance factors prevailing in the literature (i.e., board of director characteristics, CEO compensation, costs associated with earnings management, and additional firm characteristics). We then examine whether the voluntary adoption has any effect on disciplining earnings management behaviors, and whether the effect is conditional on the board independence. Empirically, we use the difference-in-differences method employing a two-way cohort-period fixed effect regression. ${ }^{7}$ We find that earnings management declines following the voluntary adoption for firms with higher level of board independence. No such results can be observed with a less independent board. Overall, we conclude only a more independent board can be relied on to carry on a disincentive mechanism such as clawback provisions at firm-level.

Our study makes several contributions. First, we examine the effect of intricate governance mechanisms on improving overall financial reporting quality. Divergent interests between mangers and investors create a demand for monitoring mechanisms to mitigate agency costs (Jensen and Meckling, 1976; Fama and Jensen, 1983; Watts and Zimmerman, 1986). Corporate governance consists of applying various monitoring and bonding mechanisms to ensure that manager's interests are aligned with those of shareholders (Shleifer and Vishny, 1997; Holthausen and Larcker, 1999; Bushman and Smith, 2001; Lambert, 2001). Little is known about how these various intricate mechanisms simultaneously shape various aspects of corporate governance, and whether there will be incremental effects when we combine (some of) them. As noted by Denis (2012, p.198): "Top executive compensation, internal control systems, boards of directors, and regulation are all important components of corporate governance systems. From an extensive and still-expanding body of literature on corporate governance we know that the various governance mechanisms interact in potentially important ways. However, we have much left to learn about the specifics of these interactions." Our paper, therefore, provides direct evidence on how one disincentive mechanism (i.e., compensation clawbacks) interacts with an enhanced monitoring mechanism (an independent board) to constrain agency costs associated with earnings management.

Second, our study contributes to a better understanding of the role of board independence. A growing body of literature confirms the importance of an independent board (Linck, et. al., 2008; Burks, 2010; Collins, et. al., 2009; Laux, 2007; Wang, 2010). A recent study however, still calls additional attention to the role of independent boards in corporate governance (Armstrong, et. al., 2010). While the proportion of outside directors has steadily increased in recent years, the board independence might also have its own imitations in corporate governance. Conventional wisdom tells us that an independent board is unlikely to serve as a panacea to completely preempt earnings management behavior. Compared with inside board members, outside directors require a highly transparent information environment to govern and advise effectively. Further, the recent surge of outside directors in the board structure could simply a response to regulatory pressure and not be the result from innate needs for stronger board monitoring. Our findings suggest that a more independent board may not fully eliminate managerial rent extraction. Rather, the corporate governance is a multiple-dimension process.

Finally, our study complements the growing body of research on the voluntary adoption of clawback provisions. Researchers point out the importance of private versus public enforcement in securities regulation (La Porta, et. al., 2006). Yet other researchers support both private and public enforcement functions (Dyck, et. al., 2010). Further, a seminal work identifies four primary governance mechanisms that serve to reduce agency conflicts: legal and regulatory mechanisms, internal control mechanisms, external control mechanisms, and product market competitions (Jensen, 1993). The firm-specific 
clawback provisions shift the responsibility of enforcement and interpretation of clawbacks from regulatory mechanisms, described as "a blunt instrument" by Jensen, to internal control mechanisms. Thus, the voluntary adoption of clawback provisions provides an importance opportunity to evaluate whether corporate executives can be sanctioned at firm-level by discretions of the board of directors.

To our best knowledge, few have examined the effect of adoption of clawback on changes earnings quality, one of the fundamental goals underpinning the "Dodd-Frank Act". Rather, concurrent papers examine voluntary clawbacks by either focusing on the determinants of the adoption decision, or the effect of clawback provisions on stock markets, audit fees, and CEO compensation. For instance, recent findings demonstrate the propensity of voluntary adoption increases with firm size and decreases with CEO entrenchment (Addy, et. al., 2014; Brown, et. al., 2011). Other works indicate that voluntary clawbacks are associated with higher earnings response coefficients (ERC), lower audit fees, and the incidence of financial restatements declines after the adoption (Chan, et. al., 2012). In addition, re2searchers observe voluntary clawbacks are associated with a decline in forecast dispersions among financial analysts, an increase in the sensitivity of cash compensation to accounting performance, as well as an increase in compensation for CEOs (Dehann, et. al., 2011). Similarly, researchers also find bid ask spreads for adopting firms decline post adoption (Gao, et. al., 2011). These results suggest market participants view firms adopting compensation clawbacks as having increased their financial reporting quality and the lowered their information risk.

Yet on the other hand, there are some inconsistent results existing in current findings among studies on voluntary clawback provisions. One argument is that a significant decline in the market's response to expected earnings after the adoption of fraud and performance based clawback provisions (Friday, et. al., 2011). They propose that voluntary adoption of clawback provisions could be motivated by other motives, such as signaling or correcting a ruined reputation. They warn that an unintended consequence of clawbacks is the deterioration of the established relation between reported earnings and stock price. Moreover, some investigators (Denis, 2012, p.198) cast doubts on the conclusions reached in Chan et. al. 2012 (CCCY thereafter) that voluntary adoption of clawback provisions leads to increased financial integrity. The argument is that the findings in CCCY are also consistent with a scenario "in which auditors' erroneous belief that a firm who adopts clawback provisions will issue more accurate reports leads them to examine the firm's financial statement less carefully, thereby reducing the likelihood that they will find a materials misstatement that requires a restatement." (Denis, 2012, p.199). Similarly, the reduction in the financial analysts' forecast dispersions could be also caused by their erroneous belief that earnings become more sustainable for voluntary adopting firms. Moreover, Denis (2012) points out another alternative interpretation on the current empirical findings, that is, "the board's new-found commitment, rather than the clawback provision in and of itself, that leads to more accurate financial reporting." Our paper attempts to untangle these alternative explanations by investigating the incremental effect of firm-specific clawbacks in tandem with an independent board. Further, we focus on earnings quality rather than the market reaction, which may be driven by erroneous beliefs of auditors and financial analysts, unrealistic estimates of future cash flows, or simply contaminated by the market sentiments or other news in the proxy statement surrounding the voluntary adoption.

We organize the remainder of this paper as follows. In Section 2, we develop our hypotheses, followed by an overview of our sample and data in Section 3. In Section 4, we present our empirical results, and we provide concluding remarks in Section 5.

\section{HYPOTHESIS DEVELOPMENT}

\section{Compensation Clawbacks and Earnings Management}

Accrual accounting gives managers substantial latitude to manage reported earnings in a desired direction. The accounting and finance literature has long recognized that managers may use latitude in accounting rules to manage reported earnings in a wide variety of contexts (reviewed by Schipper, 1989; Healy and Wahlen, 1999; Fields, et. al., 2001). Earnings are also a tool used by management to signal future cash flows. Earnings management may therefore deter investors from making informed decisions 
by giving them false or misleading information. To the extent that earnings management makes financial information more opaque to investors, it may be viewed as an agency cost.

Executives derive a considerable amount of compensation from incentive based pay (i.e. bonuses and equity) that is directly or indirectly tied to quantifiable performance metrics (Fried and Shilon, 2011). The justification for such executive pay arrangements is that increasing the sensitivity of managerial wealth to stock price (pay-performance-sensitivity) should better align managerial behavior with the interests of shareholders (Jensen and Meckling, 1976; Myers, 1977; Haugen and Senbet, 1981). But research also documents that executives manipulate earning or withhold financial information to receive higher levels of bonus income (Healy, 1985; Healy, et. al., 1987; Guidry, et. al., 1999; Gaver, et. al., 1995; Hothausen, et. al., 1995), more favorable grant date stock prices (Yermack, 1997; Aboody and Kasznik, 2000; Baker, et al, 2003; Lie, 2005; Bergstresser and Philippon, 2006; Burns and Kedia, 2006; Efendi, et. al., 2007; McAnally, et. al., 2008; Baker, et. al., 2009) or favorable stock prices prior to the exercise or sale of stock based compensation (Bartov and Mohanram, 2004; Bergstresser and Philippon, 2006; Burns and Kedia 2006; Johnson, et. al., 2009; Kedia and Philippon, 2010).

Firm-specific compensation clawback clauses increase the costs of managerial malfeasance by empowering shareholders and the board of directors to sanction their executives and seek remedies within the legal system (Fried and Shilon, 2011). Absent a recoup feature in place and in the presence of agency problems, it is extremely difficult or costly for shareholders to pursue managers' ill-gotten compensation (Glater, 2005). Rather than recouping ill-gotten pay, Burks (2009) finds that the board withholds future bonuses after restatements. The primary reason for such behavior is that the board, absent a clause in the employment contract granting power to claw back excess compensation from an executive, lacks the legal authority to do so (Glater, 2005). Even when the board fires wrong-doing managers, they can still keep the compensation they received based on the misstated accounting numbers (Chan, et. al., 2011). With clawback provision in place, however, firms may seek to claw back all compensation earned as a result of false financial numbers, regardless of fault. Based in unjust enrichment theory (Bebchuck and Fried 2005), who note that "the governing principle should be what wasn't earned must be returned." Thus, penalties under the firm-specific compensation clawbacks mitigate executives incentives to manipulate earnings. Furthermore, researchers notice such a disincentive mechanism does not "penalize operational decisions; rather, they decrease the expected gain from misreporting those decisions." (Dehaan, et. al., 2011). In this sense, clawback provisions reduce agency costs by strengthening the relation between compensation and reported earnings. In peculiar, clawback reduces the amount of firm value diverted away from shareholders through erroneous financial statements, and destroyed as a byproduct when the markets wreak havoc on accounting scandals (Fried and Shilon, 2011).

\section{The Board Independence and Clawback Adoption}

As noted above, firm-specific clawback provisions shift the responsibility for designation, interpretation, and enforcement of clawback clauses primarily from the regulatory mechanism, the SEC, to internal control mechanisms, the board of directions (Cook, 2010). The board of directors has received considerable attention in the literature. Prior literature classifies board activities into two major functions: monitoring (scrutinizing management) and advising (assisting management with decisions) (Adams and Ferreira, 2007; Raheja, 2005). The composition of the board of directors, namely the proportion of independent directors on the board, is believed to be one of the strongest predictors of effectiveness of board monitoring. Regulators as well as some academics believe that outside (independent) directors are generally more effective monitors than inside (non-independent) directors. For example, the SarbanesOxley Act and securities exchange rules in 2002 began requiring that the majority of the board be independent, while numerous studies link the proportion of outside directors to financial performance and shareholder wealth (e.g. Rosenstein and Wyatt, 1990; Byrd and Hickman, 1992; Brickley, et. al., 1994; Cotter, et. al., 1997).

Others see constraints in independent boards (Drymiotes, 2007). In a theoretical setting, Drymiotes (2007) shows that less independent boards can sometimes be more effective at monitoring. A fully independent board has an incentive to shirk from monitoring ex post, after knowing the agents productive 
inputs are sunk. In related studies, Klein (1998) suggests a positive relation between firm performance and the number of inside directors; while Bhagat and Black (2002) find there is no evidence that firms with more independent boards are more profitable. Echoing this evidence, Bebchuk and Fried (2003) warns that managerial power might compromise the independence of the board, leading to substantially inefficient compensation arrangements that yield weak or perverse incentives. Bushman et. al., (2004, p.179) suggest "Outsiders are more independent of a firm's CEO, but are potentially less informed regarding firm projects than insiders", implying the additional difficulty the independent board faces when combating rent-extracting behaviors at firm-level.

Boards with more independent directors may choose not to adopt clawback provisions because management is adequately monitored. Still, more independent boards may choose to adopt clawbacks. First, more independent boards may adopt clawbacks to signal to the market their willingness to comply and to commit to quality corporate governance. According to signaling theory (Spence, 1973), firms initiate actions to convey positive information from informed insiders to uninformed shareholders to reduce information asymmetry. For a signal to be effective it must be costly for other firms to mimic. Clawbacks are costly to executives in the form of potential loss in compensation and therefore expensive for poorly governed firms to copy. ${ }^{8}$ As such, empirical findings suggest a positive market reaction to the announcement of voluntary clawback provisions (Gao, et. al., 2011; Chan, et. al., 2012). However, the authors do not specifically examine whether the market reaction to clawback adoption is conditional on the characteristic of the board.

Empirical studies have produced equivocal results on the impact of the board of directors on the adoption of clawback provisions. Prior work finds for a cross-section of firms voluntarily adopting clawback provisions in 2007 and 2008, firms with higher level of an index (more independent monitoring) are more likely to adopt clawback provisions (Addy, et, al., 2014). But their index measure also includes CEO duality which has been shown to have an equivocal effect on board monitoring. ${ }^{9}$ Additionally, prior work suggests that firms with greater board independence are more likely to adopt clawback provisions (Gao, et. al., 2011). Conversely, some empirical findings show that while the voluntary clawback adoption is unrelated to board independence, it is positively related to board size (Brown, et. al., 2011). A limitation of these studies is that they employ a pooled logit model to examine time series cross-sectional data (panel data), which may produce inconsistent estimates (Baltagi, 2008).

Given the inconsistent findings in prior studies we treat the effect of board independence on the voluntary adoption of clawback provisions as an empirical question, we conjecture that for the board to be able to adopt the compensation clawbacks, it should have power (e.g., highly independent board). We introduce our first testable hypothesis:

\section{H1. The propensity of clawback adoption increases in board independence.}

\section{The Propensity of Clawback Adoption and the Accounting Environment}

The relation between board independence and clawback adoption could be conditional on the accounting environment of the firm. Since managers more easily manipulate earnings via aggressive vs. conservative accounting (Ahmed and Duellman, 2007), the perceived value of clawbacks will be greater for firms with lower levels of earnings quality, whose shareholders are in the danger of wealth expropriation. Research shows that more independent boards are associated with better earnings quality (Klien, 2002; Xie, et. al., 2007). On the other hand, the findings of Dyck, et. al., (2010) indicate that corporate insiders (such as management or the board of directors) are more likely to detect corporate fraud than the SEC or other outsiders. Though an independent board can be more independent from management influence, it may lack timely insights and intuitions to detect managers' rent-seeking behaviors compared to a board consisting of more insider members (Bushman, et. al., 2004). These arguments suggest that an independent board may need additional contracting mechanisms, such as clawback provisions to mitigate earnings management. Moreover, framework developed by Jensen (1993) argues that monitoring high growth firms is costly. In addition, monitoring costs increase with a firm's complexity (Fama and Jensen, 1983). Studies on board independence generally suggest board 
independence should increase optimally with operating and financial complexity (Lehn, et. al., 2004; Boone, et. al. 2007; Coles, et. al., 2007). Thus more independent boards coexist naturally in the presence of operating and financial complexity, and enhanced contracting mechanisms are needed to prevent managers from expropriating wealth from shareholders. This leads to our second hypothesis that reveals how the accounting environment may affect the relation between board independence and decision on clawback adoption:

\section{H2. An independent board will adopt compensation clawbacks mainly when earnings management is} high.

\section{Clawbacks and Post-Adoption Earnings Quality}

Lastly, concurrent papers examining clawbacks generally document improvements in the perceived financial reporting quality post the voluntary adoption. For example, Chan et. al. (2012) document that clawback provisions improve earnings response coefficients, and that auditors are less likely to report material internal control weaknesses, charge lower audit fees, and issue audit reports with shorter lag following adoption. Similarly, Gao et. al. (2011) find that bid ask spreads for adopting firms decline post adoption. Dehaan et. al., (2011) show evidence of a decreased in meet-or-beat behavior and unexplained audit fees when comparing adopting with control firms. They also document there is a decrease in restatements following the adoption as well as voluntary adopters experience a significant increase in earnings response coefficients and a significant decrease in analyst forecast dispersion. Conversely, other empirical findings suggest a significant decline in the market response to earnings surprises following clawback adoption (Friday, et. al., 2011).

However, researchers question the interpretations of these findings. For example, a decline of restatements following clawback adoption could be caused by managers' disincentives to file amended financial statements (Dehaan, et. al., 2011). It could be also due to auditors' erroneous belief - that is, a voluntarily adopting firm will issue more accurate reports so that auditors examine the financial statements with lower level of efforts (Denis, 2012). Similarly, the decrease in financial analysts' forecasts could be caused by their misconceptions that earnings of adopting firms are more sustainable. Yet, a more subtle issue is that clawback adoption could signal the board's larger commitment to internal control. Thus, it is not the clawback in and of itself that affects the financial reporting quality. To untangle multiple interpretations of the extant findings, we focus on the incremental effect of clawbacks in the presence of an independence board on mitigating earnings management. Further, we employ discretionary accruals, a common proxy for earnings quality, ${ }^{10}$ rather than the market based measures as our main variable to attenuate results caused by market participant's erroneous beliefs and sentiments.

We note that clawback provisions have their detractors. Bainbridge (2011) refers to the executive compensation provisions of Dodd-Frank Act as "another example of quack corporate governance" forced on companies by the federal governance, noting that the act's mandatory clawbck provision has "high probability of unintended consequences". If this true, then there will be no improvement in earnings quality post the clawback adoption.

Nonetheless, we draw on prior studies finding of the importance of an independent board in internal control (Hermalin and Weisbach, 2003; Shleifer and Vishny, 1997; Doyle, et. al., 2007; Laux 2007; Linck, et. al., 2008; Adams, et. al., 2009; Burks, 2010; Collins, Masli, et. al., 2009; Wang, 2010), and argue that an independent board may require additional contracting mechanisms to constrain managerial behavior. Therefore, we posit an independent board is more powerful in implementing and enforcing the provisions once the clawback provisions are in place, we predict:

\section{H3. The deterrent effect of clawbacks will be stronger in the presence of a more independent board.}




\section{SAMPLE SELECTION \& DATA}

\section{Sample selection}

Data on voluntary adoption of clawback provisions are from the July 1, 2010 Corporate Library database. The ending period of our sample, fiscal year 2009, is important because it includes only voluntary clawback provision adoptions, made prior to the enactment of Dodd-Frank Act in 2010 that requires mandatory clawback provision adoption. ${ }^{11}$ The Corporate Library identifies 638 firms disclosing clawback provisions in the 2010 proxy season (see Table 1). We require Compustat, Execucomp, Risk Metrics, and Thompson $13 \mathrm{~F}$ data for our analysis. This limits our sample to $425 \mathrm{~S} \& \mathrm{P} 1500$ firms. ${ }^{12} \mathrm{We}$ also eliminate financial firms (SIC 6000 - 6999) because firms receiving funds under the Troubled Asset Relief Program (TARP) were required to adopt clawback provisions in executive compensation plans. This further reduces our sample to 321 non-financial S\&P 1500 firms. We then identify the clawback provision adoption year using annual proxy filings. In the cases where the firm does not explicitly state when the clawback provisions were adopted, we assume that the clawback provisions were adopted in the year corresponding to the first mention of a clawback provision in a proxy. For example, if a firm announced a clawback provision in its April, 2008 proxy statement, its adopting fiscal year will be 2007 ( $t$ $=0)$. We are able to identify the first year of the clawback provision adoption for 320 firms. Our final matched sample with complete Compustat, Execucomp, Risk Metrics, and Thompson 13F data consists of 253 firms that adopt clawback provisions from 2001 to 2009. This sample is comparable to other studies examining clawback adoption by S\&P 1500 firms over a similar period. ${ }^{13}$

\section{TABLE 1}

\section{SAMPLE SELECTION}

\begin{tabular}{lr}
\hline Firms with Clawback Provisions per The Corporate Library (July 1, 2010) & 638 \\
Less Non-S\&P 1500 firms & -213 \\
\hline S\&P 1500 firms with Clawback Provisions & 425 \\
Less Financial firms (SIC 6000 - 6999) & -104 \\
\hline Non-financial S\&P 1500 firms with Clawback Provisions & 321 \\
Less firms without Clawback Provision without identifiable start date of provision & -1 \\
\hline Non-financial S\&P 1500 firms with Clawback Provisions with identifiable start date of provision & 320 \\
Less firms with incomplete data & -67 \\
\hline Final Sample & 253 \\
\hline
\end{tabular}

\section{Sample distribution}

Table 2 provides the distribution of firms that adopted clawback provisions by year, industry, and type of provisions. Panel A provides a breakdown of the adoption by year. The majority of our sample adopts clawback provisions after 2005, with 25 (9.88\%) adopting in 2006, 79 (31.23\%) adopting in 2007, 96 (37.94\%) adopting in 2008, and 41 (16.21\%) adopting in 2009. Panel B provides a breakdown of the adoption by 17 industry classifications of Fama-French (1997). Adopting firms appear clustering to Drugs, Soap, Perfumes, Tobacco (6.72\%), machinery and business equipment (13.83\%), transportation $(6.72 \%)$, and retail stores (11.07). Panel C provides a breakdown of clawback provisions by type of provision. The majority of firms adopt a fraud-based compensation provision, 127 (50.4\%), while 88 (34.92\%) adopt a performance based provision, and 37 (14.68\%) adopt a non-compete provision. 
TABLE 2

SUMMARY STATISTICS

Panel A: Clawback provision adoption by year

\begin{tabular}{ccc}
\hline Fiscal Year & Frequency & Percent \\
\hline & & \\
2001 & 1 & 0.40 \\
2003 & 3 & 1.19 \\
2004 & 3 & 1.19 \\
2005 & 5 & 1.98 \\
2006 & 25 & 9.88 \\
2007 & 79 & 31.23 \\
2008 & 96 & 37.94 \\
2009 & 41 & 16.21 \\
\hline & & \\
Total & 253 & 100 \\
\hline
\end{tabular}

Panel B: Clawback provision adoption by industry

\begin{tabular}{ccc}
\hline Fama-French 17 Industry & Frequency & Percent \\
\hline Food & 15 & 5.93 \\
Mining and Minerals & 4 & 1.58 \\
Oil and Petroleum Products & 11 & 4.35 \\
Textiles, Apparel \& Footwear & 5 & 1.98 \\
Consumer Durables & 7 & 2.77 \\
Chemicals & 12 & 4.74 \\
Drugs, Soap, Perfumes, Tobacco & 17 & 6.72 \\
Construction and Construction Materials & 9 & 3.56 \\
Steel Works Etc & 4 & 1.58 \\
Fabricated Products & 2 & 0.79 \\
Machinery and Business Equipment & 35 & 13.83 \\
Transportation & 17 & 6.72 \\
Utilities & 15 & 5.93 \\
Retail Stores & 28 & 11.07 \\
Other & 72 & 28.46 \\
\hline & & \\
Total & 253 & 100 \\
\hline
\end{tabular}

Panel C: Clawback provisions by type

\begin{tabular}{ccc}
\hline Clawback type & Frequency & Percent \\
\hline Fraudulent & 127 & 50.40 \\
Performance Based & 88 & 34.92 \\
Non-Compete & 37 & 14.68 \\
\hline Total & 252 & 100 \\
\hline
\end{tabular}

\section{Variable descriptions}

Our primary variables are earnings quality, board of director characteristics, CEO compensation, costs associated with earnings management, and other firm specific controls. We detail the construction of the variables and data sources in more detail in Appendix A. All variables are winsorized at upper and 
lower $1 \%$ of the sample distribution each year to address potential problems associated with extreme observations. Next, we discuss on our main and control variables.

\section{Earnings Management}

We use discretionary accruals (DA) to proxy for earnings quality following prior literature. Discretionary accruals measure the difference between observed accruals and the normal level of accruals. We estimated the normal level of accruals using the magnitude of the residual from the modified Jones model with an additional control for performance. Researchers later suggest the need to control for performance when estimating abnormal accruals (Kothari et. al., 2005, p. 165 KLW thereafter): "Conceptually, our motivation for controlling for performance stems from the simple model of earnings, cash flows, and accruals in Dechow et al. (1998). This model shows that working capital accruals increase in forecasted sales growth and earnings because of a firm's investment in working capital to support the growth in sales. Therefore, if performance exhibits momentum or mean reversion (i.e., performance deviates from a random walk), then predicted accruals would be non-zero." Based on suggestions from Dechow et al. (1998) that accruals relate to performance and the empirical superiority of ROA-based matching over other variables documented by Barber and Lyon (1996), KLW (2005) recommend using industry-level ROA to control for performance. ${ }^{1} \mathrm{KLW}$ find that adding ROA to MJ significantly improves estimates of abnormal accruals. Following KLW (2005), we estimate the following regression:

$\frac{T A C C_{i, t}}{A T A_{i, t}}=\alpha \frac{1}{A T A_{i, t}}+\beta_{1} \frac{\Delta R E V_{i, t}-\Delta R E C_{i, t}}{A T A_{i, t}}+\beta_{2} \frac{P P E_{i, t}}{A T A_{i, t}}+\beta_{3} \frac{E A R N_{i, t}}{A T A_{i, t}}$

where,

$T A C C_{i, t}=$ total accruals for firm $i$ in year $t$;

$\triangle R E V_{i, t}=$ change in sales revenue firm $i$ in year $t$;

$\triangle R E C_{i, t}=$ change in account receivables firm $i$ in year $t$

$P P E_{i, t}=$ gross property, plant, and equipment for firm $i$ in year $t$;

$E A R N_{i, t}=$ earnings before extraordinary items for firm $i$ in year $t$;

$A T A_{i, t}=$ average total assets for firm $i$ in year $t$.

We measure DA as the magnitude of the residual from equation (1). We run the regression by industry-year and require at least 10 observations available. ${ }^{14}$

\section{Board of Director Characteristics}

Our primary proxy for effective monitoring by the board of directors is the proportion of independent directors on the board (PIND). We also control for board size (BDSIZE) and CEO duality (DUALITY). Small boards are assumed to be better than large ones because large boards place a greater emphasis on "politeness and courtesy", making it easier for CEOs to control. Empirical studies support this idea (e.g. Yermack, 1996; Eisenberg, et. al., 1998). CEO duality, whether the CEO also holds the title of chairman of the board, may reflect the concentration of power in the CEO's position and allow the CEO to control information available to other directors impeding effective monitoring (Jensen, 1993). Lastly, we control for the time that the CEO has served in the position of CEO (TENURE).

\section{CEO Compensation}

Prior studies show the mixture of CEO compensation affects CEO incentives to manage earnings (Healy, 1985; Hothausen, et. al., 1995; Yermack, 1997; Aboody and Kasznik, 2000; Bergstresser and Philippon, 2006; Burns and Kedia, 2006; Efendi, et al. 2007, Bartov and Mohanram, 2004; McAnally, et. al., 2008). The extent to which managers manage earnings could reveal the strength of existing corporate governance; more importantly, it could affect the board's decision on voluntarily adopting clawback provisions. Therefore, we include CEO compensation in our research design. We measure CEO compensation using the proportion of bonus-based compensation (PBONUS) and option-based 
compensation (POPTION) to total annual compensation. These two variables are proxies for whether executives have compensation-related reasons to misrepresent firm performance.

\section{Costs Associated with Earnings Management}

We include several control variables to control for firm characteristics that are related to accruals quality. Following Zang (2012), we use nine proxies for the costs associated with earnings management: market share (MKTSHR), Altman's Z-score (ZSCORE), institutional ownership (INSTOWN), marginal tax rates (MTR) ${ }^{15}$, whether the firm's auditor is one of the Big 8 accounting firms (BIG8), auditor tenure (ATENURE), whether the observation is from the post-SOX (Sarbanes-Oxley) period (SOX), net operating assets (NOAS), and the length of the operating cycle (CYCLE). A large percentage of sample firms $(\sim 25 \%)$ have missing values for marginal tax rate. We set these missing values to zero, and create an indicator variable (MISSMTR) equal to 1 when this value it is missing. Firms with higher market shares and in healthier financial condition (a higher Altman's Z-score) have lower costs associated with earnings management, while firms with higher levels of institutional ownership and marginal tax rates have higher costs associated with earnings management. The scrutiny on firms' accounting practices will increase when firms are audited by Big 8 accounting firms or during the post-SOX period. Lastly, firms with higher net operating assets at the beginning of the year have less flexibility to manage earnings, while firms with longer operating cycles have greater flexibility to manage earnings. ${ }^{16}$

\section{Other Control Variables}

We control for additional firm characteristics using the log of total assets (LNTA), return on assets (ROA), and Tobin's Q (Q). All variables are measures in the same year relative to the observation.

\section{Research Design and Descriptive Statistics}

We begin by providing descriptive statistics for those variables that we expect to be associated with clawback provision adoption. For each clawback provision adopting firm we first form a comparison group of non-adopting firms that were in the same Fama and French (1997) 49 industry classification as the adopting firm in the year prior to adoption $(\mathrm{t}=-1)$. We then construct a cohort of adopting and nonadopting firms using the two years before $(t=-2)$ to the two years after adoption $(t=+2)$. Firms are not required to be in the sample for the full five years around adoption. Our sample is comprised of 3,592 firms (253 adopting firms and 3,339 non-adopting control firms) and 14,377 firm-year observations from 1999 to 2009 . Table 3 provides descriptive statistics for our sample. 
TABLE 3

DESCRIPTIVE STATISTICS

All variables are defined in Section 3.3 and Appendix A.

\begin{tabular}{cccccccc}
\hline Variable & Mean & S.D. & Min & $\mathbf{2 5 \%}$ & $\mathbf{5 0 \%}$ & $\mathbf{7 5 \%}$ & Max \\
\hline DA & -0.0020 & 0.0657 & -0.2564 & -0.0307 & 0.0011 & 0.0326 & 0.1741 \\
LNTA & 7.5500 & 1.4238 & 4.7681 & 6.4976 & 7.4341 & 8.4853 & 10.9236 \\
ROA & 0.0484 & 0.0912 & -0.3790 & 0.0239 & 0.0534 & 0.0928 & 0.2684 \\
Q & 1.9040 & 1.0669 & 0.7545 & 1.2119 & 1.5481 & 2.2181 & 6.7078 \\
DUALITY & 0.5360 & 0.4987 & 0.0000 & 0.0000 & 1.0000 & 1.0000 & 1.0000 \\
TENURE & 8.5114 & 7.0808 & 1.0000 & 3.0000 & 6.0000 & 11.0000 & 34.0000 \\
BDSIZE & 9.0180 & 2.0932 & 5.0000 & 7.0000 & 9.0000 & 10.0000 & 14.0000 \\
PIND & 0.7606 & 0.1234 & 0.4000 & 0.6667 & 0.7778 & 0.8750 & 0.9231 \\
PBONUS & 0.2111 & 0.1673 & 0.0000 & 0.0833 & 0.1906 & 0.3044 & 0.7316 \\
POPTION & 0.2546 & 0.2539 & 0.0000 & 0.0000 & 0.2007 & 0.4057 & 1.0000 \\
MKTSHARE $_{\mathrm{t}-1}$ & 0.0751 & 0.1383 & 0.0001 & 0.0039 & 0.0178 & 0.0768 & 0.8107 \\
ZSCORE & 5.1462 & 5.0840 & -0.0900 & 2.2900 & 3.7400 & 6.0000 & 32.6000 \\
MTR & 0.2349 & 0.1569 & 0.0000 & 0.0000 & 0.3500 & 0.3500 & 0.391032 \\
MISSMTR $_{\text {INSTOWN }}$ & $\mathbf{8 1 . 2 4 9 5}$ & 0.4327 & 0.0000 & 0.0000 & 0.0000 & 0.0000 & 1.0000 \\
BIG8 & 0.9496 & 16.2405 & 35.3287 & 72.0038 & 84.2340 & 95.0835 & 100.0000 \\
ATENURE & 10.2308 & 4.9512 & 1.0000 & 6.0000 & 11.0000 & 15.0000 & 18.0000 \\
SOX & 0.9559 & 0.2053 & 0.0000 & 1.0000 & 1.0000 & 1.0000 & 1.0000 \\
NOAS $_{\text {t-1 }}$ & 0.7295 & 0.5783 & -0.0360 & 0.3275 & 0.5634 & 0.9538 & 2.9409 \\
CYCLE $_{\mathrm{t}-1}$ & 71.2101 & 62.6915 & -91.0800 & 32.7400 & 60.4050 & 100.5300 & 286.6600 \\
\hline
\end{tabular}

\section{EMPIRICAL RESULTS}

\section{Board Independence, Earnings Management, and the Likelihood of Clawback Provision Adoption}

We begin by examining the joint influence of board independence and prior - adoption earnings quality on the likelihood of clawback provision adoption. Table 4 reports the number of clawback adopting firms and the predicted probability of clawback provision adoption using adopting and nonadopting industry-matched cohort firms in the year of clawback provision adoption $(t=0)$. Panel A reports the number of firms adopting or not adopting clawback provisions categorized by the level of board independence and earnings management in the year prior to adoption $(t=-1)$. Firms are classified as having high board independence (low earnings quality) if the proportion of independent directors (the level of discretionary accruals) is greater than the sample median in the year prior to adoption. A total of 237 firms, approximately $6.6 \%(=237 / 3,592)$ of our sample, adopt clawback provisions. However, the number of adopting firms also increases in board independence. We find that $135(=65+70)$ firms with high board independence adopt clawback provisions, compared with only $111(=57+46)$ adopting firms with low board independence. Further, firms with high board independence and low level of earnings quality represent the highest number of adopting firms in our sample (70). A chi-square test indicates a statistically significant relation between board independence and earnings quality and the number of firms adopting clawback provisions.

We next examine the likelihood of clawback adoption in a multivariate framework. We estimate the following binary logit model using adopting and non-adopting industry-matched cohort firms in the year of clawback provision adoption $(\mathrm{t}=0)$ to examine whether board independence and prior-adoption earnings qaulity affects the propensity of clawback provision adoption:

$$
C L A W_{i}=\alpha+\beta X_{i}+\varepsilon_{i}
$$


where $i$ indexes firm. CLAW is a binary variable equal to 1 if a firm adopts a clawback provision at time $\mathrm{t}$ and 0 otherwise. $X_{i t}$ is a vector of control variables measured at time $\mathrm{t}=-1$ (lagged 1 year relative to the adoption year). $\varepsilon_{i t}$ is an error term. We cluster standard errors at the firm-cohort level.

Panel B reports estimates of logit regressions of the propensity to adopt clawback provisions. Column 1 provides coefficient estimates and column 2 provides average marginal effects (or discrete changes for binary variables), which describe how each of our independent variables affect the probability of the firm adopting a clawback provision. ${ }^{17}$ Several control variables are statistically significant. The coefficient estimates for whether the CEO also holds the title of chairman of the board (DUALITY), the proportion of bonus compensation to total compensation (PBONUS), auditor tenure (ATENURE), size (LNTA), post-SOX (SOX), and the proportion of firms in the same Fama-French 49 industry that have adopted a clawback provision (PFF49ADOPT) are positive and significant, while the coefficient estimate for CEO tenure (TENURE), net operating assets (NOA), and Z-score (ZSCORE) are negative and significant.

Panel $\mathrm{C}$ reports the predicted probability of clawback provision adoption categorized by the level of board independence and earnings management in the year prior to adoption $(\mathrm{t}=-1)$. The average (median) predicted probability of clawback provision adoption for our sample is $0.0660(0.0511)$. But we also find that firms with high board independence have significantly higher predicted probabilities of clawback adoption than firms with lower board independence. The mean (median) predicted probability of clawback provision adoption for high board independence firms is $0.0815(0.05734)$, compared to a mean (median) predicted probability of clawback provision adoption for low board independence firms of 0.0529 (0.0383). Further, firms with both high board independence and low prior-adoption earnings quality have the highest predicted probability of the voluntary adoption. The mean (median) predicted probability for high board independence and high earnings management firms is $0.0844(0.0614)$.

Overall, our results suggest that clawback provisions are more likely to be adopted by firms with high board independence. In addition, firms with both high board independence and a low prior-adoption earnings quality have the greatest likelihood of adoption. This is consistent with the view that a more independent board may not completely eliminate managerial rent extraction via earnings management. As such, the board may seek other disciplinary tools, such as clawback provisions, to deal with earnings management.

TABLE 4

PROPENSITY OF CLAWBACK PROVISION ADOPTION

All observations are for the year of adoption $(t=0)$. Heteroskedasticity robust $t$-statistics clustered at the firmcohort level are given in parentheses. Superscripts $* / * * / * * *$ indicate levels of significance of $10 \%, 5 \%$, and $1 \%$, respectively.

Panel A: Number of adopting firms

\begin{tabular}{lccccccc}
\hline \multirow{2}{*}{ Board Independence } & \multicolumn{2}{c}{ Low } & \multicolumn{2}{c}{ High } & \multicolumn{2}{c}{} \\
\cline { 2 - 6 } Earnings management & Low & High & Low & High & Total & $\chi^{2}$ & Prob. \\
\hline Not adopting & 932 & 913 & 742 & 768 & 3,355 & 12.62 & 0.006 \\
Adopting & 57 & 46 & 65 & 69 & 237 & & \\
\hline Total & 989 & 959 & 807 & 837 & 3,592 & \\
\hline
\end{tabular}


Panel B: Logit regressions of clawback provision adoption

\begin{tabular}{|c|c|c|}
\hline \multirow[t]{2}{*}{ Dependent Variable } & \multicolumn{2}{|c|}{ CLAWBACK } \\
\hline & (1) & (2) \\
\hline Independent Variable & $\begin{array}{c}\text { Coefficient } \\
\text { Estimates }\end{array}$ & $\begin{array}{c}\text { Average Marginal } \\
\text { Effects }\end{array}$ \\
\hline \multirow[t]{2}{*}{ BDSIZE $_{\mathrm{t}-1}$} & 0.00279 & 0.000161 \\
\hline & $(0.07)$ & $(0.07)$ \\
\hline \multirow[t]{2}{*}{ DUALITY $_{\mathrm{t}-1}$} & $0.339^{* *}$ & $0.0195^{* *}$ \\
\hline & $(2.17)$ & (2.17) \\
\hline \multirow[t]{2}{*}{ TENURE $_{\mathrm{t}-1}$} & $-0.0345^{* * *}$ & $-0.00198^{* * *}$ \\
\hline & $(-2.60)$ & $(-2.59)$ \\
\hline \multirow[t]{2}{*}{ PBONUS $_{\mathrm{t}-1}$} & $0.888^{* *}$ & $0.0511^{* *}$ \\
\hline & $(2.12)$ & $(2.12)$ \\
\hline \multirow{2}{*}{ POPTION $_{\mathrm{t}-1}$} & 0.0728 & 0.00419 \\
\hline & $(0.25)$ & $(0.25)$ \\
\hline \multirow[t]{2}{*}{ MKTSHARE $_{\mathrm{t}-1}$} & 0.304 & 0.0175 \\
\hline & $(0.87)$ & $(0.87)$ \\
\hline \multirow[t]{2}{*}{$\mathrm{ZSCORE}_{\mathrm{t}-1}$} & $-0.0327^{* *}$ & $-0.00188^{* *}$ \\
\hline & $(-1.97)$ & $(-1.97)$ \\
\hline \multirow{2}{*}{$\mathrm{MTR}_{\mathrm{t}-1}$} & 0.393 & 0.0226 \\
\hline & $(0.39)$ & $(0.39)$ \\
\hline \multirow[t]{2}{*}{ MISSMTR $_{\mathrm{t}-1}$} & 0.0882 & 0.00508 \\
\hline & $(0.24)$ & $(0.24)$ \\
\hline \multirow{2}{*}{ INSTOWN $_{\mathrm{t}-1}$} & 0.00430 & 0.000248 \\
\hline & $(0.85)$ & $(0.85)$ \\
\hline \multirow{2}{*}{$\mathrm{BIG}_{\mathrm{t}-1}$} & -0.546 & -0.0314 \\
\hline & $(-1.40)$ & $(-1.40)$ \\
\hline \multirow{2}{*}{ ATENURE $_{\mathrm{t}-1}$} & $0.0287^{*}$ & $0.00165^{*}$ \\
\hline & $(1.73)$ & $(1.73)$ \\
\hline \multirow[t]{2}{*}{ SOX } & $1.074^{*}$ & $0.0619^{*}$ \\
\hline & $(1.96)$ & $(1.96)$ \\
\hline \multirow[t]{2}{*}{$\mathrm{NOAS}_{\mathrm{t}-1}$} & $-0.437^{* * *}$ & $-0.0252^{* * *}$ \\
\hline & $(-2.99)$ & $(-2.98)$ \\
\hline \multirow{2}{*}{ CYCLE $_{\mathrm{t}-1}$} & 0.0000409 & 0.00000236 \\
\hline & $(0.46)$ & $(0.46)$ \\
\hline \multirow[t]{2}{*}{ LNTA $_{t-1}$} & $0.512^{* * *}$ & $0.0295^{* * *}$ \\
\hline & $(7.60)$ & $(7.50)$ \\
\hline \multirow[t]{2}{*}{$\mathrm{ROA}_{\mathrm{t}-1}$} & 0.735 & 0.0423 \\
\hline & $(0.67)$ & $(0.67)$ \\
\hline \multirow[t]{2}{*}{$\mathrm{Q}_{\mathrm{t}-1}$} & 0.0226 & 0.00130 \\
\hline & $(0.28)$ & $(0.28)$ \\
\hline \multirow[t]{2}{*}{ PFFIND49 ${ }_{\mathrm{t}-1}$} & $2.725^{* * *}$ & $0.157^{* * *}$ \\
\hline & $(3.07)$ & $(3.05)$ \\
\hline \multirow{2}{*}{ CONSTANT } & $-8.047^{* * *}$ & \\
\hline & $(-8.42)$ & \\
\hline$N$ & 3592 & 3592 \\
\hline
\end{tabular}


Panel C: Predicted probability of adoption by board independence and earnings management

\begin{tabular}{|c|c|c|c|c|c|c|c|c|}
\hline \multirow{2}{*}{$\begin{array}{l}\text { Board Independence } \\
\text { Discretionary Accruals }\end{array}$} & \multicolumn{2}{|c|}{ Low } & \multicolumn{2}{|c|}{ High } & \multirow[b]{3}{*}{$\boldsymbol{F}$} & \multirow[b]{3}{*}{ Prob. } & \multirow[b]{3}{*}{$x^{2}$} & \multirow[b]{3}{*}{ Prob. } \\
\hline & Low & High & Low & High & & & & \\
\hline & \multicolumn{4}{|c|}{ Pr(Adoption) } & & & & \\
\hline Mean & 0.0519 & 0.0540 & 0.07421 & 0.0844 & 64.84 & $<0.001$ & & \\
\hline Median & 0.0371 & 0.0391 & 0.0545 & 0.0614 & & & 176.53 & $<0.001$ \\
\hline $\mathrm{N}$ & 989 & 959 & 807 & 837 & & & & \\
\hline
\end{tabular}

\section{Effect of Clawback Provision Adoption on Earnings Management}

Next, we examine the effect of voluntary adoption on earnings quality post the adoption. Figure reports discretionary accruals surrounding the adoption. Again, we categorize the adopting firms by the level of board independence and earnings quality in the year prior to adoption $(t=-1)$. We find that the voluntary adoption results in an improvement in earnings quality only for firms with a high level of earnings management prior to adoption, whereas firms with low earnings management exhibit an increase in discretionary accruals. Further, the largest decrease in discretionary accruals occurs in firms with high board independence and low earnings quality prior to the adoption. Specifically, firms with high board independence and low earnings quality have slightly lower levels of discretionary accruals than firms with low board independence and low earnings quality prior to the adoption , 0.0329 versus 0.0495 respectively, the former shows a greater decline in discretionary accruals post the voluntary adoption, -0.0344 vs. -0.0146 respectively (See Table 5).

TABLE 5

DISCRETIONARY ACCRUALS SURROUNDING CLAWBACK PROVISION ADOPTION Firms are classified as having high (low) board independence if the proportion of independent directors is above (below) the sample median at clawback adoption $(\mathrm{t}=0)$. Firms are classified as having high (low) earnings management if the level of discretionary accruals is above (below) the sample median at clawback adoption $(t=0)$.

\begin{tabular}{|c|c|c|c|c|c|c|}
\hline $\begin{array}{l}\text { Board } \\
\text { Independence }\end{array}$ & $\begin{array}{l}\text { Discretionary } \\
\text { Accruals }\end{array}$ & Year -1 & Year 0 & Year 1 & $\Delta$ Year -1 to 0 & $\Delta$ Year -1 to 1 \\
\hline \multirow{2}{*}{ Low } & (1) Low & -0.0619 & -0.0035 & -0.0128 & 0.0566 & 0.0430 \\
\hline & (2) High & 0.0495 & 0.0350 & 0.0330 & -0.0146 & -0.0131 \\
\hline \multirow{3}{*}{ High } & (3) Low & -0.0415 & -0.0023 & -0.0016 & 0.0398 & 0.0354 \\
\hline & (4) High & 0.0329 & -0.0015 & 0.0078 & -0.0344 & -0.0183 \\
\hline & $\mathbf{N}$ & 237 & 232 & 200 & 232 & 200 \\
\hline$F$-test & $p$-value & $<0.001$ & $<0.001$ & $<0.001$ & $<0.001$ & $<0.001$ \\
\hline
\end{tabular}

To further test the effect of clawback provision adoption on earnings quality, we use the difference in-difference method. Similar methodologies have been used by Bertrand and Mullainathan (2003), Low (2009), and Gormley, et. al., (2011). We estimate the average treatment effect, the effect of clawback adoption on discretionary accruals, using the following two-way fixed effect regression based on the entire pooled sample of industry matched cohorts over the 5 year sample period: ${ }^{18}$

$$
D A_{i t}=\alpha_{t}+\beta_{i}+\gamma X_{i t}+\delta C L A W_{i t}^{*} B I_{i}^{*} E M_{i}+\zeta C L A W_{i t} * B I_{i}+\kappa C L A W_{i t} * E M_{i}+\varphi C L A W_{i t}+\varepsilon_{i t}
$$

where $i$ indexes firm, $t$ indexes time. DA are the discretionary accruals. $\alpha_{t}+\beta_{i}$ are period-cohort and firm-cohort fixed effects to ensure that we estimate the impact of the adoption after controlling for any secular time trends and fixed differences between firms. We allow the firm and period fixed effects to vary by cohort, which is more conservative than including simple fixed effects for firm and year. $X_{i t}$ is a vector of time-varying control variables. CLAW is an indicator that equals 1 if the firm has adopted a 
clawback provision as of period $t$. CLAW changes from 0 to 1 in the year that the firm first adopts a clawback provision $(t=0)$. BI is an indicator that equals 1 if the firm has board independence above the sample median in the year prior to adoption $(t=-1)$ and 0 otherwise. EM is an indicator that equals 1 if the firm has discretionary accruals above the sample median in the year prior to adoption $(t=-1)$ and 0 otherwise. Because the specification includes period-cohort and firm-cohort fixed effects, it is not necessary to include the non-interacted $\mathrm{BI}_{\mathrm{i}}$ and $\mathrm{EM}_{\mathrm{i}}$ indicator variables. ${ }^{19} \varepsilon_{i t}$ is an error term.

This specification takes into consideration three levels of differencing: clawback adoption versus non clawback adoption, high board independence versus low board independence, and low earnings quality versus high earnings quality. The sum of the estimated coefficients $\delta, \zeta, \kappa$, and $\varphi$ indicates the effect of the voluntary adoption on earnings quality for firms with high board independence and low earnings quality, the sum of the estimated coefficients $\zeta$ and $\varphi$ indicates the effect of the voluntary adoption on earnings quality for firms with high board independence and low earnings quality prior to the adoption, the sum of the estimated coefficients $\kappa$ and $\varphi$ indicates the effect of the voluntary adoption on earnings quality for firms with low board independence and low earnings quality prior to the adoption, and the estimated coefficient $\varphi$ indicates the effect of the adoption on earnings quality for firms with low board independence and high earnings quality prior to the adoption.

This method compares the within-firm change in earnings quality for a firm surrounding the adoption period, and it compares this change with that of a non-adopting industry-matched cohort firm over the same period. As such, each firm serves as its own control group. An advantage of this method is that it removes a potentially large source of omitted variable bias because the firm-cohort fixed effects, $\beta_{i}$, taking into account any observable or unobservable firm specific factors that are time-invariant. We implement this method in a regression framework to allow for time-varying firm characteristics, $X_{i t}$, which may also bias our estimate of the treatment effect. We cluster standard errors at the firm-cohort level.

Table 6 reports estimates from a fixed-effect regression of the effect of the voluntary adoption on discretionary accruals. Panel A reports estimated effect of the voluntary adoption on earnings quality for adopting firms split by the level of board independence and earnings quality in the year prior to adoption $(t=-1)$. Panel B reports the estimates for the entire model. Our results are consistent with the trends presented in Table 5. The adoption is associated with significant increase in earnings quality for firms with low level of earnings quality prior to the adoption. Holding the earnings quality level prior to the adoption constant, the difference of earnings quality post adoption between high board independence and low board independence firms is salient. The coefficient for the high board independence firm is -0.0066 $=0.0123-0.00437-0.0335+0.0189$, whereas the coefficient for low board independence firm is $-0.0145=-0.0335+0.0189$.

Conversely, the voluntary adoption is associated with significant decrease in earnings quality for firms with high earnings quality prior to adoption. For firms with high earnings quality prior to the adoption, the discretionary accruals increase post the adoption. The estimated coefficients for high board independence and low earnings management $(0.0146=-0.00437+0.0189)$ and low board independence and low earnings management (0.0189) are positive and significant. Additionally, adopting firms with low board independence and high earnings quality prior to adoption see the largest increase in earnings management following the voluntary adoption. One possible explanation for this finding is for firms with high earnings quality prior the adoption, the disincentive mechanism serves as a substitute to the board's monitoring function. Since the earnings quality is already high prior to the adoption, with the additional deterrent effect from the clawback provisions, the board could presumably lessen its monitoring efforts, leading to increases in the discretionary accruals post the voluntary adoption. The effect is more pronounced for firms with a less independent board prior to the adoption.

The estimates in Table 6 , however, might be subject to certain bias since the voluntary adoption could be endogenously formed like other internal governance mechanisms (Hermaline and Weisbach, 2003). To eliminate the endogeneity problem of simultaneity bias, we endogenize the adoption decision using the proportion of firms in the same Fama-French 49 industry as firm $i$ that have adopted a clawback provisions in time $t=-1$ (FF49ADOPT) as an instrument for the adoption decision. We expect that this 
variable will be highly correlated with the adoption decision, but uncorrelated with discretionary accruals. This assumption is supported statistically. A Davidson-MacKinnon (1993) test for endogeneity is significant at the $1 \%$ supporting the use of the fixed effect two-stage least squares model. Further, when conducting two-stage least squares for the set of instruments, they must also be highly correlated with the endogenous regressors, but uncorrelated with the disturbance process. The first condition, that the set of instruments is sufficiently correlated with the endogenous regressors, is supported by significant estimated coefficients and $F$ statistics from the first stage regressions for the set of instruments that are significant at the $10 \%$ level (see Table 6 below), a Kleibergen-Paap (2007) LM statistic (underidentification test) that is significant at the $10 \%$ level, and a Cragg-Donald Wald $\mathrm{F}$ statistic (weak identification test) that exceeds the Stock-Yogo weak ID critical values at $20 \%$. The latter condition, that the set of instruments is uncorrelated with (orthogonal to) the disturbance process can be supported by a non-significant Hansen-Sargan $J$-statistic. A failure to reject the null hypothesis would imply that our instruments also satisfy the orthogonality condition. However, this can only be estimated in an overidentified model (i.e. more instruments than endogenous variables).

\section{TABLE 6 \\ FIRM-COHORT FIXED EFFECT REGRESSIONS OF DISCRETIONARY ACCRUALS ON CLAWBACK PROVISION ADOPTION}

Panel A presents estimated coefficients and $p$-values for firms with a high level of discretionary accruals and high level of board independence (the sum of the estimated coefficients on CLAW, CLAWEM, CLAWBI, and CLAWEMBI), a high level of discretionary accruals and low level of board independence (the sum of the estimated coefficients on CLAW and CLAWEM), a low level of discretionary accruals and high board independence (the sum of the estimated coefficients on CLAW and CLAWBI), and a low level of discretionary accruals and low board independence (the estimated coefficient on CLAW), where the estimated coefficients are from the regression in Panel B. CLAW is an indicator variable that equals one if the firm adopts a clawback provision in year $t$ and zero otherwise. EM is an indicator variable that equals one if the firm has above median discretionary accruals in year t-1 and zero otherwise. BI is an indicator variable that equals one if the firm has above median board independence in year $\mathrm{t}-1$ and zero otherwise. All regressions include firm-cohort and period-cohort fixed effects. Superscripts $* / * * / * * *$ indicate levels of significance of $10 \%, 5 \%$, and $1 \%$, respectively.

Panel A. Estimated coefficients by groups

\begin{tabular}{lrl} 
Group & Estimated Coefficient & $\boldsymbol{p}$-value \\
\hline High BI \& High EM & -0.0066 & $<0.001$ \\
High BI \& Low EM & 0.0146 & $<0.001$ \\
Low BI \& High EM & -0.0145 & $<0.001$ \\
Low BI \& Low EM & 0.0189 & $<0.001$ \\
\hline
\end{tabular}

Panel B: Regression results

\begin{tabular}{cc}
\hline Dependent Variable & DA \\
\hline Independent Variable & Estimated Coefficient \\
\hline CLAWBIEM & 0.0123 \\
& $(1.09)$ \\
CLAWBI & -0.00437 \\
& $(-0.55)^{* * *}$ \\
CLAWEM & $-0.0335^{* *}$ \\
& $(-3.79)^{* *}$ \\
CLAW & $0.0189^{*}$ \\
& $(3.14)$ \\
BDSIZE & 0.000211 \\
& $(0.31)$ \\
DUALITY & $-0.00760^{* * *}$ \\
& $(-2.80)$
\end{tabular}




\begin{tabular}{|c|c|}
\hline TENURE & $\begin{array}{l}0.000157 \\
(0.84)\end{array}$ \\
\hline PBONUS & $\begin{array}{c}-0.0214^{* * *} \\
(-5.06)\end{array}$ \\
\hline POPTION & $\begin{array}{c}-0.00327 \\
(-1.12)\end{array}$ \\
\hline MKTSHARE $_{\mathrm{t}-1}$ & $\begin{array}{c}-0.00997 \\
(-0.43)\end{array}$ \\
\hline $\mathrm{ZSCORE}_{\mathrm{t}-1}$ & $\begin{array}{c}-0.00212^{* * *} \\
(-6.54)\end{array}$ \\
\hline MTR & $\begin{array}{c}-0.00297 \\
(-0.34)\end{array}$ \\
\hline MISSMTR & $\begin{array}{c}-0.00377 \\
(-0.91)\end{array}$ \\
\hline INSTOWN & $\begin{array}{c}-0.000105 \\
(-1.06)\end{array}$ \\
\hline BIG8 & $\begin{array}{c}0.0181^{* *} \\
(2.04)\end{array}$ \\
\hline ATENURE & $\begin{array}{c}0.0000677 \\
(0.20)\end{array}$ \\
\hline SOX & $\begin{array}{c}-0.0000254 \\
(-0.00)\end{array}$ \\
\hline $\mathrm{NOAS}_{\mathrm{t}-1}$ & $\begin{array}{c}-0.00455 \\
(-1.39)\end{array}$ \\
\hline CYCLE $_{\mathrm{t}-1}$ & $\begin{array}{c}-0.000128^{* * *} \\
(-3.61)\end{array}$ \\
\hline LNTA & $\begin{array}{c}-0.00676^{*} \\
(-1.92)\end{array}$ \\
\hline ROA & $\begin{array}{l}0.559^{* * *} \\
(40.26)\end{array}$ \\
\hline Q & $\begin{array}{c}-0.0103^{* * *} \\
(-6.62)\end{array}$ \\
\hline irm-cohort Effects & Yes \\
\hline riod-cohort Effects & Yes \\
\hline$N$ & 14377 \\
\hline $\mathrm{n}$ & 3592 \\
\hline $\mathrm{R}^{2}$ Within & 0.397 \\
\hline $\mathrm{R}^{2}$ Between & 0.00279 \\
\hline $\mathrm{R}^{2}$ Overall & 0.127 \\
\hline
\end{tabular}

Table 7 reports estimates of a fixed-effects two stage least squares regression of the effect of voluntary adoption on discretionary accruals. Panel A reports estimated effects of clawback provision adoption on earnings quality for adopting firms split by the level of board independence and earnings management in the year prior to adoption $(t=-1)$. Panel B reports the estimates for the entire model. Again, the estimated coefficient for high board independence and low earnings quality firms $(-0.0022=$ $0.360-0.353-0.381+0.372)$ is negative and significant. Earnings quality improves for firms with both high board independence and low earnings quality prior to the adoption of a clawback provision. Conversely, we are unable to conclude that there is a significant change in earnings quality for forms with low board independence and low levels of earnings management. 
Using a fixed effects model when the correct model should include a lagged dependent variable may overstate the treatment effect, but including a lagged dependent variable when the appropriate model includes fixed effects may understate the treatment effect (Angrist and Pischke, 2008). In other words, the fixed effect and lagged dependent variable models have a useful bracketing property. Further, the fixed effect model assumes that omitted variable bias arises from a time-invariant unit-level factor, whereas, the lagged dependent variable model assumes that omitted variable bias arises from time-varying pretreatment trends. To assess the robustness of our model, we re-run our tests using a model that includes a lagged dependent variable.

\section{TABLE 7}

\section{FIRM-FIXED EFFECT TWO-STAGE LEAST SQUARES REGRESSIONS OF DISCRETIONARY ACCRUALS ON CLAWBACK PROVISION ADOPTION}

Panel A presents estimated coefficients and p-values for firms with a high level of discretionary accruals and high level of board independence (the sum of the estimated coefficients on CLAW, CLAWEM, CLAWBI, and CLAWEMBI), a high level of discretionary accruals and low level of board independence (the sum of the estimated coefficients on CLAW and CLAWEM), a low level of discretionary accruals and high board independence (the sum of the estimated coefficients on CLAW and CLAWBI), and a low level of discretionary accruals and low board independence (the estimated coefficient on CLAW), where the estimated coefficients are from the regression in Panel B. CLAW is an indicator variable that equals one if the firm adopts a clawback provision in year $t$ and zero otherwise. EM is an indicator variable that equals one if the firm has above median discretionary accruals in year t- 1 and zero otherwise. BI is an indicator variable that equals one if the firm has above median board independence in year $\mathrm{t}-1$ and zero otherwise. Superscripts $* / * * * * *$ indicate levels of significance of $10 \%, 5 \%$, and $1 \%$, respectively.

Panel A. Estimated coefficients by groups

\begin{tabular}{lrl} 
Group & Estimated Coefficient & $\boldsymbol{p}$-value \\
\hline High BI \& High EM & -0.0022 & $<0.001$ \\
High BI \& Low EM & 0.0186 & 0.0540 \\
Low BI \& High EM & -0.0095 & 0.0427 \\
Low BI \& Low EM & 0.3718 & 0.257 \\
\hline
\end{tabular}

Panel B: Regression results

\begin{tabular}{lc}
\hline Dependent Variable & DA \\
\hline Independent Variable & Estimated Coefficient \\
\hline CLAWBIEM & 0.360 \\
& $(1.12)$ \\
CLAWBI & -0.353 \\
& $(-1.09)$ \\
CLAWEM & -0.381 \\
& $(-1.18)$ \\
CLAW & 0.372 \\
& $(1.13)$ \\
BDSIZE & -0.000524 \\
& $(-0.54)$ \\
DUALITY & $-0.00658^{* *}$ \\
TENURE & $(-2.18)$ \\
PBONUS & 0.0000919 \\
POPTION & $(0.38)$ \\
& $-0.0300^{* * *}$ \\
& $(-5.69)$ \\
& -0.00403 \\
& $(-1.02)$
\end{tabular}




\begin{tabular}{|c|c|}
\hline MKTSHARE $_{\mathrm{t}-1}$ & $\begin{array}{l}-0.0119 \\
(-0.38)\end{array}$ \\
\hline $\mathrm{ZSCORE}_{\mathrm{t}-1}$ & $\begin{array}{c}-0.00200^{* * *} \\
(-4.97)\end{array}$ \\
\hline MTR & $\begin{array}{c}-0.00392 \\
(-0.39)\end{array}$ \\
\hline MISSMTR & $\begin{array}{c}-0.00675 \\
(-1.32)\end{array}$ \\
\hline INSTOWN & $\begin{array}{c}-0.000117 \\
(-1.01)\end{array}$ \\
\hline BIG8 & $\begin{array}{r}0.0157^{*} \\
(1.68)\end{array}$ \\
\hline ATENURE & $\begin{array}{c}0.000503 \\
(0.99)\end{array}$ \\
\hline SOX & $\begin{array}{l}-0.0162 \\
(-1.21)\end{array}$ \\
\hline NOAS $_{t-1}$ & $\begin{array}{c}-0.00490 \\
(-1.32)\end{array}$ \\
\hline CYCLE $_{t-1}$ & $\begin{array}{c}-0.0000760^{*} \\
(-1.76)\end{array}$ \\
\hline LNTA & $\begin{array}{c}-0.00773^{*} \\
(-1.91)\end{array}$ \\
\hline $\mathrm{ROA}$ & $\begin{array}{l}0.548^{* * *} \\
(39.92)\end{array}$ \\
\hline Q & $\begin{array}{c}-0.0111^{* * *} \\
(-6.45)\end{array}$ \\
\hline $\begin{array}{l}\text { Firm-cohort Effects } \\
\text { Period-cohort Effects }\end{array}$ & $\begin{array}{l}\text { Yes } \\
\text { Yes }\end{array}$ \\
\hline \multicolumn{2}{|l|}{ Tests of excluded instruments } \\
\hline$F$ & $3.17 *$ \\
\hline \multicolumn{2}{|l|}{ Underidentification test } \\
\hline Kleibergen-Paap rk LM statistic & $3.202 *$ \\
\hline \multicolumn{2}{|l|}{ Weak identification test } \\
\hline Cragg-Donald Wald F statistic & $7.086>$ C.V. \\
\hline$N$ & 14121 \\
\hline
\end{tabular}

Table 8 reports the estimates of a lagged dependent variable two stage least squares regression of the effect of voluntary adoption on discretionary accruals. Panel A reports estimated effects of the adoption on earnings quality for adopting firms split by the level of board independence and earnings quality in the year prior to adoption $(t=-1)$. Panel $B$ reports the estimates for the entire model. The estimated coefficient for high board independence and low earnings quality $(-0.0023=-0.432+0.412+0.450-$ 0.432 ) is negative and significant. Again, the estimated coefficient for low board independence and low earnings quality $(0.0179=0.450-0.432)$ is positive and significant. The estimated coefficients for high board independence and high earnings quality firms $(-0.0200=0.412-0.432)$ is now negative and significant. Overall, our conclusions remain unchanged. Earnings quality improves following the adoption for firms with high board independence and low earnings quality prior to adoption. The results from a lagged dependent model, however, also suggest that earnings quality declines following the voluntary adoption if firms has low board independence and low earnings quality prior to the adoption. 
This indicates that clawback provisions, absent an independent board, may not mitigate agency costs associated with the earnings management.

TABLE 8

\section{LAGGED DEPENDENT VARIABLE TWO-STAGE LEAST SQUARES REGRESSIONS OF DISCRETIONARY ACCRUALS ON CLAWBACK PROVISION ADOPTION}

Panel A presents estimated coefficients and p-values for firms with a high level of discretionary accruals and high level of board independence (the sum of the estimated coefficients on CLAW, CLAWEM, CLAWBI, and CLAWEMBI), a high level of discretionary accruals and low level of board independence (the sum of the estimated coefficients on CLAW and CLAWEM), a low level of discretionary accruals and high board independence (the sum of the estimated coefficients on CLAW and CLAWBI), and a low level of discretionary accruals and low board independence (the estimated coefficient on CLAW), where the estimated coefficients are from the regression in Panel B. CLAW is an indicator variable that equals one if the firm adopts a clawback provision in year $t$ and zero otherwise. EM is an indicator variable that equals one if the firm has above median discretionary accruals in year t-1 and zero otherwise. BI is an indicator variable that equals one if the firm has above median board independence in year t-1 and zero otherwise. All regressions include firm-cohort and period-cohort fixed effects. Superscripts $* / * * / * * *$ indicate levels of significance of $10 \%, 5 \%$, and $1 \%$, respectively.

Panel A. Estimated coefficients by groups

\begin{tabular}{lrl} 
Group & Estimated Coefficient & $p$-value \\
\hline High BI \& High EM & -0.0023 & $<0.001$ \\
High BI \& Low EM & -0.0200 & 0.0459 \\
Low BI \& High EM & 0.0179 & $<0.001$ \\
Low BI \& Low EM & -0.4322 & 0.117 \\
\hline
\end{tabular}

Panel B: Regression results

\begin{tabular}{lc}
\hline Dependent Variable & DA \\
\hline Independent Variable & Estimated Coefficient \\
\hline DA $_{\mathrm{t}-1}$ & -0.00677 \\
CLAWBIEM & $(-0.27)$ \\
& -0.432 \\
CLAWBI & $(-1.60)$ \\
& 0.412 \\
CLAWEM & $(1.53)$ \\
& $0.450^{*}$ \\
CLAW & $(1.66)$ \\
& -0.432 \\
BDSIZE & $(-1.57)$ \\
& -0.000594 \\
DUALITY & $(-1.14)$ \\
TENURE & -0.00232 \\
& $(-1.30)$ \\
PBONUS & 0.000147 \\
& $(1.19)$ \\
POPTION & 0.00283 \\
& $(0.42)$ \\
MKTSHARE & $-0.00918^{* * *}$ \\
ZSCORE & $(-3.01)$ \\
& 0.00372 \\
& $(0.57)$ \\
& $-0.00210^{* * *}$ \\
& $(-8.94)$
\end{tabular}




$\begin{array}{lc}\text { MTR } & -0.0522^{* * *} \\ & (-5.12)^{* * *} \\ \text { MISSMTR } & -0.0140^{* *} \\ & (-3.06) \\ \text { INSTOWN } & -0.000183^{* * *} \\ & (-3.21)^{* * *} \\ \text { BIG8 } & -0.0173^{* *} \\ & (-2.79) \\ \text { ATENURE } & 0.000131 \\ & (0.59) \\ \text { SOX } & 0.00551 \\ & (1.05) \\ \text { NOAS } & -0.00185 \\ & (-0.85) \\ \text { CYCLE } & \\ & 0.0000684^{* * *} \\ \text { LNTA } & (5.48) \\ & -0.000328 \\ \text { ROA } & (-0.20) \\ & 0.375^{* *} \\ \text { Q } & (23.97) \\ & -0.0153^{* * *} \\ \text { Firm-cohort Effects } & (-10.38) \\ \text { Period-cohort Effects } & \\ & \text { Yes } \\ & \text { Yes }\end{array}$

\begin{tabular}{lc}
\hline Tests of excluded instruments & \\
\hline$F$ & $3.30^{*}$ \\
\hline Underidentification test & $3.278^{*}$ \\
\hline Kleibergen-Paap rk LM statistic & \\
\hline Weak identification test & $13.135>$ C.V. \\
\hline Cragg-Donald Wald F statistic & 14073 \\
\hline$N$ & \\
\hline
\end{tabular}

Lastly, our previous two-stage least squares models endogenize clawback provision adoption (CLAW), while also including several interaction terms with this variable (CLAWBIEM, CLAWBI, and CLAWEM). These interaction terms may also suffer from simultaneity bias. But the number of interaction terms in our model further complicates this problem and the potential stability of the model. Our previous results, however, also suggest that firms with high earnings management prior to clawback provision adoption (with either high or low board independence) reduce earnings management following clawback provision adoption. Thus, we adjust our model specification to the following:

$$
D A_{i t}=\alpha_{t}+\beta_{i}+\gamma X_{i t}+\delta C L A W_{i t}^{*} E M_{i}+\zeta C L A W_{i t}+\varepsilon_{i t}
$$

where the definition of variables is as in Model (3). This specification takes into consideration only two levels of differencing: clawback adoption versus non-clawback adoption and high earnings management versus low earnings management. The sum of the estimated coefficients $\delta$ and $\zeta$ indicates the effect of clawback provision adoption on earnings management for firms with high earnings management and $\zeta$ indicates the effect of clawback provision adoption on earnings management for firms with low earnings management. 
We then treat CLAWEM as endogenous and include an additional instrument for CLAWEM which is the product of FF49ADOPT and EM (an indicator that equals 1 if the firm has discretionary accruals above the sample median in the year prior to adoption, $\mathrm{t}=-1$, and 0 otherwise) in our two-stage model. Again, the validity of our instrumental variables are supported by significant estimated coefficients and $F$ statistics from the first stage regressions for the set of instruments that are significant at the $1 \%$ level (see Table 9 below), a Kleibergen-Paap (2007) LM statistic (underidentification test) that is significant at the $1 \%$ level, and a Kleibergen-Paap rk Wald $\mathrm{F}$ statistic (weak identification test) that exceeds the critical values.

TABLE 9

FIRM-FIXED EFFECT TWO-STAGE LEAST SQUARES REGRESSIONS OF DISCRETIONARY ACCRUALS ON CLAWBACK PROVISION ADOPTION

CLAW is an indicator variable that equals one if the firm adopts a clawback provision in year $t$ and zero otherwise. $\mathrm{EM}$ is an indicator variable that equals one if the firm has above median discretionary accruals in year t- 1 and zero otherwise. Superscripts $* / * * / * * *$ indicate levels of significance of $10 \%, 5 \%$, and $1 \%$, respectively.

\begin{tabular}{|c|c|c|c|}
\hline Dependent Variable & CLAW & CLAWEM & DA \\
\hline Independent Variable & (1) & (2) & (3) \\
\hline CLAW & & & $\begin{array}{c}0.324^{* * *} \\
(4.40)\end{array}$ \\
\hline CLAWEM & & & $\begin{array}{c}-0.315^{* * *} \\
(-4.36)\end{array}$ \\
\hline$F$ & & & $18.10 * * *$ \\
\hline PIND & $\begin{array}{c}0.108^{* * *} \\
(3.66)\end{array}$ & $\begin{array}{c}0.0201^{*} \\
(1.73)\end{array}$ & $\begin{array}{c}-0.0159 \\
(-1.06)\end{array}$ \\
\hline BDSIZE & $\begin{array}{c}0.00457^{* *} \\
(2.04)\end{array}$ & $\begin{array}{c}0.00231^{*} \\
(1.86)\end{array}$ & $\begin{array}{c}-0.000457 \\
(-0.46)\end{array}$ \\
\hline DUALITY & $\begin{array}{c}0.00286 \\
(0.32)\end{array}$ & $\begin{array}{c}-0.00220 \\
(-0.54)\end{array}$ & $\begin{array}{c}-0.00853^{* *} \\
(-2.33)\end{array}$ \\
\hline TENURE & $\begin{array}{c}-0.0000226 \\
(-0.04)\end{array}$ & $\begin{array}{c}0.000460^{*} \\
(1.94)\end{array}$ & $\begin{array}{c}0.000238 \\
(0.90)\end{array}$ \\
\hline PBONUS & $\begin{array}{c}0.00581 \\
(0.54)\end{array}$ & $\begin{array}{c}-0.00429 \\
(-0.76)\end{array}$ & $\begin{array}{c}-0.0405^{* * *} \\
(-7.30)\end{array}$ \\
\hline POPTION & $\begin{array}{c}-0.0151^{* *} \\
(-2.21)\end{array}$ & $\begin{array}{c}-0.00579^{*} \\
(-1.96)\end{array}$ & $\begin{array}{c}-0.00107 \\
(-0.28)\end{array}$ \\
\hline LNTA & $\begin{array}{c}0.00570 \\
(0.75)\end{array}$ & $\begin{array}{c}0.00497 \\
(1.25)\end{array}$ & $\begin{array}{c}-0.0162^{* * *} \\
(-3.64)\end{array}$ \\
\hline ROA & $\begin{array}{c}0.00170 \\
(0.08)\end{array}$ & $\begin{array}{c}-0.0199 \\
(-1.62)\end{array}$ & $\begin{array}{l}0.686^{* * *} \\
(28.90)\end{array}$ \\
\hline Q & $\begin{array}{c}-0.00835^{* * *} \\
(-3.19)\end{array}$ & $\begin{array}{c}-0.00308^{* * *} \\
(-3.30)\end{array}$ & $\begin{array}{c}-0.0170^{* * *} \\
(-10.04)\end{array}$ \\
\hline MKTSHARE $_{t-1}$ & $\begin{array}{l}0.0273 \\
(0.42)\end{array}$ & $\begin{array}{l}0.0164 \\
(0.51)\end{array}$ & $\begin{array}{l}0.0135 \\
(0.46)\end{array}$ \\
\hline $\mathrm{ZSCORE}_{\mathrm{t}-1}$ & $\begin{array}{c}-0.000318 \\
(-0.54)\end{array}$ & $\begin{array}{c}0.0000685 \\
(0.56)\end{array}$ & $\begin{array}{c}-0.00265^{* * *} \\
(-6.01)\end{array}$ \\
\hline MTR & $\begin{array}{c}-0.0127 \\
(-0.63)\end{array}$ & $\begin{array}{c}0.00304 \\
(0.38)\end{array}$ & $\begin{array}{c}0.00871 \\
(0.66)\end{array}$ \\
\hline MISSMTR & $\begin{array}{c}-0.0177^{*} \\
(-1.94)\end{array}$ & $\begin{array}{c}-0.00149 \\
(-0.43)\end{array}$ & $\begin{array}{c}-0.000316 \\
(-0.06)\end{array}$ \\
\hline
\end{tabular}




\begin{tabular}{|c|c|c|c|}
\hline INSTOWN & $\begin{array}{c}0.000523^{* *} \\
(2.18)\end{array}$ & $\begin{array}{c}0.000279^{* * *} \\
(2.86)\end{array}$ & $\begin{array}{c}-0.000276^{* *} \\
(-2.27)\end{array}$ \\
\hline BIG8 & $\begin{array}{l}-0.0198^{* *} \\
(-1.99)\end{array}$ & $\begin{array}{c}-0.00562^{* *} \\
(-2.34)\end{array}$ & $\begin{array}{c}0.0226^{* *} \\
(2.33)\end{array}$ \\
\hline ATENURE & $\begin{array}{l}0.00293^{* * *} \\
(2.62)\end{array}$ & $\begin{array}{c}0.00127^{* * *} \\
(3.24)\end{array}$ & $\begin{array}{c}0.000340 \\
(0.63)\end{array}$ \\
\hline SOX & $\begin{array}{c}0.00192 \\
(0.25)\end{array}$ & $\begin{array}{c}-0.000464 \\
(-0.12)\end{array}$ & $\begin{array}{l}-0.0157^{* * *} \\
(-3.79)\end{array}$ \\
\hline NOAS $_{t-1}$ & $\begin{array}{l}-0.0101 \\
(-1.20)\end{array}$ & $\begin{array}{c}-0.00485 \\
(-1.23)\end{array}$ & $\begin{array}{l}-0.0135^{* * *} \\
(-2.65)\end{array}$ \\
\hline CYCLE $_{t-1}$ & $\begin{array}{c}0.0000366 \\
(0.48)\end{array}$ & $\begin{array}{c}0.0000506 \\
(1.14)\end{array}$ & $\begin{array}{c}-0.0000554 \\
(-1.20)\end{array}$ \\
\hline $\mathrm{RDS}_{\mathrm{t}-1}$ & $\begin{array}{l}0.0125 \\
(0.40)\end{array}$ & $\begin{array}{l}-0.0170 \\
(-1.19)\end{array}$ & $\begin{array}{c}0.329^{* * *} \\
(9.83)\end{array}$ \\
\hline $\mathrm{TDTA}_{\mathrm{t}-1}$ & $\begin{array}{l}0.0131 \\
(0.59)\end{array}$ & $\begin{array}{c}0.00833 \\
(0.89)\end{array}$ & $\begin{array}{l}0.0167 \\
(1.23)\end{array}$ \\
\hline LOSS & $\begin{array}{c}0.00317 \\
(0.56)\end{array}$ & $\begin{array}{c}0.000946 \\
(0.34)\end{array}$ & $\begin{array}{c}0.00797^{* *} \\
(2.21)\end{array}$ \\
\hline DVPOR $_{t-1}$ & $\begin{array}{c}-0.0000378 \\
(-0.78)\end{array}$ & $\begin{array}{c}-0.0000393 \\
(-1.58)\end{array}$ & $\begin{array}{c}0.0000326 \\
(1.32)\end{array}$ \\
\hline SDOCFTA & $\begin{array}{l}0.0734 \\
(0.95)\end{array}$ & $\begin{array}{c}0.0732^{*} \\
(1.66)\end{array}$ & $\begin{array}{l}-0.264^{* * *} \\
(-4.33)\end{array}$ \\
\hline SDSALETA & $\begin{array}{l}-0.0140 \\
(-0.68)\end{array}$ & $\begin{array}{l}-0.0178 \\
(-1.61)\end{array}$ & $\begin{array}{c}0.00431 \\
(0.35)\end{array}$ \\
\hline OANCFTA $_{t-1}$ & $\begin{array}{c}0.00960 \\
(0.39)\end{array}$ & $\begin{array}{l}-0.0105 \\
(-1.10)\end{array}$ & $\begin{array}{l}0.0527^{* * *} \\
(2.66)\end{array}$ \\
\hline PFFIND49 & $\begin{array}{c}0.152^{* * *} \\
(3.44)\end{array}$ & $\begin{array}{c}-0.0943^{* * *} \\
(-5.63)\end{array}$ & \\
\hline PFFIND49 X HIGHEM & $\begin{array}{l}4.069^{* * *} \\
(15.23)\end{array}$ & $\begin{array}{l}4.267^{* * *} \\
(15.79)\end{array}$ & \\
\hline $\begin{array}{l}\text { Firm-cohort Effects } \\
\text { Period-cohort Effects }\end{array}$ & $\begin{array}{l}\text { Yes } \\
\text { Yes }\end{array}$ & $\begin{array}{l}\text { Yes } \\
\text { Yes }\end{array}$ & $\begin{array}{l}\text { Yes } \\
\text { Yes }\end{array}$ \\
\hline Tests of excluded instruments & & & \\
\hline$F$ & $118.14 * * *$ & $208.31 * * *$ & \\
\hline Underidentification test & & & \\
\hline Kleibergen-Paap rk LM statistic & & & $32.73 * * *$ \\
\hline Weak identification test & & & \\
\hline Cragg-Donald Wald F statistic & & & $18.458>\mathrm{C} . \mathrm{V}$ \\
\hline$N$ & 14056 & 14056 & 14056 \\
\hline
\end{tabular}

Table 9 report estimates of a fixed-effects two stage least squares regression of the effect of clawback provision adoption on discretionary accruals, while Table 10 reports estimates of a lagged dependent variable two stage least squares regression of the effect of clawback provision adoption on discretionary accruals. The results remain consistent with the previous ones. On one hand, earnings quality improves following the voluntary adoption if the board is more independent and earnings quality is relatively low prior to the adoption. On the other hand, earnings quality declines most post the adoption if the board is less independent and earnings quality was relatively high prior to the adoption. 


\section{TABLE 10}

\section{LAGGED DEPEDENT VARIABLE TWO-STAGE LEAST SQUARES REGRESSIONS OF DISCRETIONARY ACCRUALS ON CLAWBACK PROVISION ADOPTION}

CLAW is an indicator variable that equals one if the firm adopts a clawback provision in year $t$ and zero otherwise. EM is an indicator variable that equals one if the firm has above median discretionary accruals in year $\mathrm{t}-1$ and zero otherwise. Superscripts $* * * / * * *$ indicate levels of significance of $10 \%, 5 \%$, and $1 \%$, respectively.

\begin{tabular}{|c|c|c|c|}
\hline Dependent Variable & CLAW & CLAWEM & DA \\
\hline Independent Variable & (1) & (2) & (3) \\
\hline CLAW & & & $\begin{array}{c}0.114^{* * *} \\
(3.44)\end{array}$ \\
\hline CLAWEM & & & $\begin{array}{c}-0.0891^{* * *} \\
(-2.78)\end{array}$ \\
\hline$F$ & & & $46.57 * * *$ \\
\hline $\mathrm{DA}_{\mathrm{t}-1}$ & $\begin{array}{c}-0.0245 \\
(-0.91)\end{array}$ & $\begin{array}{c}0.0585^{* * *} \\
(4.59)\end{array}$ & $\begin{array}{c}-0.0894^{* * *} \\
(-7.16)\end{array}$ \\
\hline PIND & $\begin{array}{c}0.0377^{* *} \\
(2.33)\end{array}$ & $\begin{array}{c}0.00862 \\
(1.04)\end{array}$ & $\begin{array}{c}-0.00308 \\
(-0.61)\end{array}$ \\
\hline BDSIZE & $\begin{array}{c}0.000285 \\
(0.21)\end{array}$ & $\begin{array}{c}0.0000322 \\
(0.06)\end{array}$ & $\begin{array}{c}-0.000834^{* *} \\
(-2.30)\end{array}$ \\
\hline DUALITY & $\begin{array}{c}0.00531 \\
(1.13)\end{array}$ & $\begin{array}{c}-0.00177 \\
(-0.68)\end{array}$ & $\begin{array}{c}-0.00288^{* *} \\
(-2.30)\end{array}$ \\
\hline TENURE & $\begin{array}{c}-0.000441 \\
(-1.41)\end{array}$ & $\begin{array}{c}0.000128 \\
(0.67)\end{array}$ & $\begin{array}{l}0.000205^{* *} \\
(2.27)\end{array}$ \\
\hline PBONUS & $\begin{array}{c}0.0176 \\
(1.47)\end{array}$ & $\begin{array}{c}-0.00831 \\
(-1.43)\end{array}$ & $\begin{array}{c}-0.0190^{* * *} \\
(-5.08)\end{array}$ \\
\hline POPTION & $\begin{array}{c}-0.00738 \\
(-1.09)\end{array}$ & $\begin{array}{c}-0.00766^{* * *} \\
(-2.66)\end{array}$ & $\begin{array}{c}-0.0126^{* * *} \\
(-5.66)\end{array}$ \\
\hline LNTA & $\begin{array}{c}0.0133^{* * *} \\
(5.30)\end{array}$ & $\begin{array}{c}0.00299^{* *} \\
(2.57)\end{array}$ & $\begin{array}{c}-0.00375^{* * *} \\
(-5.39)\end{array}$ \\
\hline ROA & $\begin{array}{l}0.0265 \\
(1.08)\end{array}$ & $\begin{array}{c}0.00476 \\
(0.46)\end{array}$ & $\begin{array}{l}0.468^{* * *} \\
(31.66)\end{array}$ \\
\hline Q & $\begin{array}{c}-0.00751^{* * *} \\
(-3.83)\end{array}$ & $\begin{array}{c}-0.00285^{* * *} \\
(-3.74)\end{array}$ & $\begin{array}{c}-0.0129^{* * *} \\
(-11.64)\end{array}$ \\
\hline MKTSHARE $_{t-1}$ & $\begin{array}{c}0.0120 \\
(0.65)\end{array}$ & $\begin{array}{c}-0.00578 \\
(-1.07)\end{array}$ & $\begin{array}{c}0.00246 \\
(0.52)\end{array}$ \\
\hline $\mathrm{ZSCORE}_{\mathrm{t}-1}$ & $\begin{array}{c}-0.0000478 \\
(-0.13)\end{array}$ & $\begin{array}{c}0.000183 \\
(1.57)\end{array}$ & $\begin{array}{c}-0.00128^{* * *} \\
(-6.80)\end{array}$ \\
\hline MTR & $\begin{array}{c}0.0330^{*} \\
(1.70)\end{array}$ & $\begin{array}{c}0.0177^{* *} \\
(2.34)\end{array}$ & $\begin{array}{c}-0.0340^{* * *} \\
(-4.41)\end{array}$ \\
\hline MISSMTR & $\begin{array}{c}0.0146^{* *} \\
(1.99)\end{array}$ & $\begin{array}{c}0.00802^{* * *} \\
(2.62)\end{array}$ & $\begin{array}{c}-0.0130^{* * *} \\
(-4.46)\end{array}$ \\
\hline INSTOWN & $\begin{array}{c}-0.000255^{*} \\
(-1.74)\end{array}$ & $\begin{array}{l}0.0000635 \\
(0.89)\end{array}$ & $\begin{array}{c}0.0000148 \\
(0.36)\end{array}$ \\
\hline BIG8 & $\begin{array}{c}-0.0157^{*} \\
(-1.80)\end{array}$ & $\begin{array}{c}0.000399 \\
(0.18)\end{array}$ & $\begin{array}{c}-0.00647^{*} \\
(-1.83)\end{array}$ \\
\hline ATENURE & $\begin{array}{c}0.00125^{* *} \\
(2.53)\end{array}$ & $\begin{array}{c}0.000593^{* * *} \\
(2.63)\end{array}$ & $\begin{array}{c}-0.00000687 \\
(-0.05)\end{array}$ \\
\hline SOX & $0.0117^{* *}$ & $0.0113^{* * *}$ & $-0.0243^{* * *}$ \\
\hline
\end{tabular}




\begin{tabular}{|c|c|c|c|}
\hline & & & \\
\hline NOAS $_{\mathrm{t}-1}$ & $\begin{array}{c}-0.0186^{* * *} \\
(-3.90)\end{array}$ & $\begin{array}{c}-0.00590^{* * *} \\
(-2.72)\end{array}$ & $\begin{array}{c}-0.00147 \\
(-1.01)\end{array}$ \\
\hline CYCLE $_{t-1}$ & $\begin{array}{c}-0.0000172 \\
(-0.51)\end{array}$ & $\begin{array}{c}0.0000190 \\
(1.02)\end{array}$ & $\begin{array}{c}-0.00000579 \\
(-0.52)\end{array}$ \\
\hline $\mathrm{RDS}_{\mathrm{t}-1}$ & $\begin{array}{c}0.0847^{* * *} \\
(2.70)\end{array}$ & $\begin{array}{c}0.00403 \\
(0.34)\end{array}$ & $\begin{array}{l}0.0153 \\
(1.48)\end{array}$ \\
\hline TDTA $_{t-1}$ & $\begin{array}{c}-0.00552 \\
(-0.31)\end{array}$ & $\begin{array}{c}0.00971 \\
(1.21)\end{array}$ & $\begin{array}{c}-0.00116 \\
(-0.23)\end{array}$ \\
\hline LOSS & $\begin{array}{c}0.0122^{*} \\
(1.83)\end{array}$ & $\begin{array}{c}0.00269 \\
(1.04)\end{array}$ & $\begin{array}{c}-0.000639 \\
(-0.24)\end{array}$ \\
\hline DVPOR $_{t-1}$ & $\begin{array}{c}-0.0000269 \\
(-0.51)\end{array}$ & $\begin{array}{c}-0.00000260 \\
(-0.09)\end{array}$ & $\begin{array}{c}0.0000154 \\
(0.98)\end{array}$ \\
\hline SDOCFTA & $\begin{array}{c}-0.0112 \\
(-0.14)\end{array}$ & $\begin{array}{l}0.0100 \\
(0.27)\end{array}$ & $\begin{array}{l}-0.0396 \\
(-1.37)\end{array}$ \\
\hline SDSALETA & $\begin{array}{c}-0.00745 \\
(-0.46)\end{array}$ & $\begin{array}{c}-0.00967 \\
(-1.20)\end{array}$ & $\begin{array}{c}-0.0187^{* * *} \\
(-3.51)\end{array}$ \\
\hline OANCFTA $_{t-1}$ & $\begin{array}{c}0.0821^{* *} \\
(2.38)\end{array}$ & $\begin{array}{c}0.00927 \\
(0.56)\end{array}$ & $\begin{array}{l}-0.317^{* * *} \\
(-20.51)\end{array}$ \\
\hline PFFIND49 & $\begin{array}{c}0.153^{* * *} \\
(3.29)\end{array}$ & $\begin{array}{c}-0.131^{* * *} \\
(-7.19)\end{array}$ & \\
\hline PFFIND49 X HIGHEM & $\begin{array}{l}4.952^{* * *} \\
(14.13)\end{array}$ & $\begin{array}{l}5.324^{* * *} \\
(15.17)\end{array}$ & \\
\hline CONSTANT & $\begin{array}{c}-0.0972^{* * *} \\
(-4.46)\end{array}$ & $\begin{array}{c}-0.0334^{* * *} \\
(-3.00)\end{array}$ & $\begin{array}{l}0.129^{* * *} \\
(16.72)\end{array}$ \\
\hline Tests of e & & & \\
\hline$F$ & $101.64 * * *$ & $232.84 * * *$ & \\
\hline Underidentification test & & & \\
\hline Kleibergen-Paap rk LM statistic & & & $39.40 * * *$ \\
\hline Weak identification test & & & \\
\hline Cragg-Donald Wald F statistic & & & $21.983>$ C.V. \\
\hline$N$ & 14025 & 14025 & 14025 \\
\hline
\end{tabular}

\section{CONCLUSION}

The theory of "managerial power" implies that the board of directors is part of agency problem itself (Bebchuk and Fried, 2003). Bebchuk and Fried (2003) point out that "Just as there is no reason to presume managers automatically seek to maximize shareholder value, there is no reason to expect a priori that directors will either. Indeed, an analysis of directors' incentive and circumstances suggests that directors' behavior is also subject to an agency problem". Clawback provisions are now viewed as a best practice in corporate governance (Melbinger, 2010) and prominent legal academics argue for even more robust clawback policies going forward (Fried and Shilon, 2011). However, board of directors is entitled a lot of discretions during the development, interpretation and enforcement of firm-specific clawback provisions under the requirements of Dodd-Frank Act (Cook, 2010). Major concerns arise as whether board of directors will use their discretions out of good faith in this process.

In contrast with other concurrent papers examining the determinants and consequences of the voluntary adoption, we focus on the effectiveness of board of directors in this private sanction process. We propose that a more independent board cannot completely eliminate managers' rent extractions. Hence, it may choose to adopt clawback provisions voluntarily. Consistent with our predictions, we find that firms with an independent board and have relatively low level of earnings quality will more likely 
adopt the clawbacks after we rule out other potentially confounding factors (i.e., board of director characteristics, CEO compensation, costs associated with earnings management, and additional firm characteristics). In addition, we find on one hand, earnings quality improves following the voluntary adoption if the board is more independent and earnings quality is relatively low prior to the adoption. On the other hand, earnings quality declines most post the adoption if the board is less independent and earnings quality was relatively high prior to the adoption. Taken together, our findings suggest that the success of voluntary adopters pivotally depends on the extent of board independence. Private enforcement likely only works in the presence of a more independent board. Further, if the earnings quality was high prior to the adoption, the board could presumably lessen its monitoring efforts post the adoption, leading to the decrease in earnings quality following the adoption. The effect is more pronounced for firms with low level of board independence. Our findings contribute to better understanding the efficacy of independent board; and how intricate governance mechanisms work together.

\section{FIGURE 1}

\section{DISCRETIONARY ACCRUALS SURROUNDING CLAWBACK PROVISION ADOPTION}

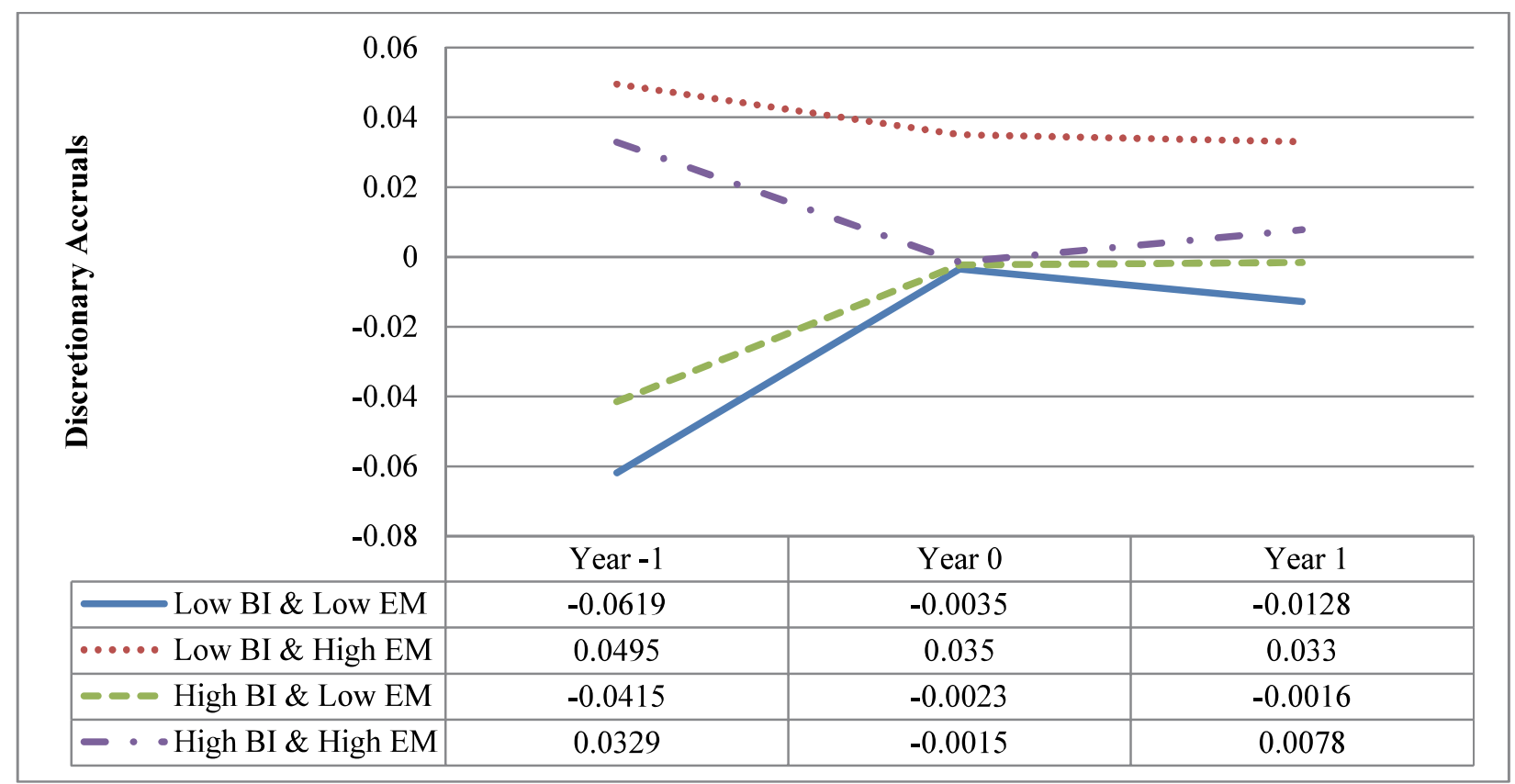

\section{ENDNOTES}

1. For instance, the SEC first invoked SOX Section 304 in 2009 when it sued Maynard Jenkins, the former CEO of CSK Auto Corp, to clawback $\$ 4.1$ million in incentive and stock-based compensation. But there was also substantial debate within the SEC in the Maynard case over its authority to clawback his pay three commissioners voted to sue Jenkins to recoup bonuses and profits from stock-sales and two commissioners voted to oppose the case (Bloomberg, 2009). Since then the SEC has evoked its clawback authority to recover compensation from executives three times, against Diebold Inc. and Navistar International in 2010, and Beazer Homes USA Inc. in 2011. The SEC chose not to claw back pay from Michael Dell (Dell Inc.) in 2010 for disclosure violations.

2. For perspective, Glass Lewis \& Co. document 440 and 945 restatements by U.S. public corporations in 2004 and 2005, respectively. Of these restatements, revenue-recognition errors -those historically associated with accounting fraud - accounted for 122 and 160 of total restatements in 2004 and 2005 alone (Turner and Weirich, 2006).

3. Pub L No 111-203, 124 Stat 1376 (2010). 
4. This mandate is embodied in Section 10D to the Securities Exchange Act of 1934. Dodd-Frank Wall Street Reform and Consumer Protection Act, H.R. Rep. 111-517, $111^{\text {th }}$ Cong, 2d Sess. \&954 (2010).

5. Other major differences between Section 954 of Dood-Frank and the SOX recovery provision include: SOX clawback can be triggered only if the restatement is the result of "misconduct", while Dodd-Frank compels recoupment of excess pay even absent from any misconduct. 2) SOX allows the recovery of all incentive pay, while Dodd-Frank requires the clawback of only certain types of excess pay (Fried and Shilon 2011).

6. Studies document the rise of equity incentives in managers' compensation arrangements has created perverse incentives for managerial misconducts including aggressive earnings managements (McAnally et al. 2008; Bartov and Mohanram 2004; Johnson et al. 2009; Kedia and Philippon 2010) and a positive association between stock-based compensation and accounting restatements (Efendi et al. 2007; Burns and Kedia 2006) over this period.

7. Similar methodologies have been used by Bertrand and Mullainathan (2003), Low (2009), and Gormley et al. (2011).

8. It is also possible that clawback adoption sends a costless signal. For example, Fried and Shilon (2011) note that the financial and reputational losses to the board and firm resulting from high-profile litigation suggests that the board is not likely to claw back pay when provided discretion to do so in the provision. For instance, Nike's clawback provision (Nike, 2010) states that "it [the board] may require the officer to repay all or part of his incentive compensation". The choice of the word "may" rather than "will" is important in that it conveys discretion to the board. Moreover, Fried and Shilon (2011) find that $81 \%$ of clawback provisions adopted by S\&P 500 firms by 2010 provide boards with similar discretion to apply clawback provisions. Crawford and Sobel (1982) show that "cheap talk", defined as a costless and nonbinding message, can still send a credible signal to the market.

9. Duality may allow the CEO to control information available to other directors impeding effective monitoring (Jensen, 1993). However, empirical work has not supported the concept that duality can lead to agency costs. For example, Brickley, Coles, and Jarrell (1997) demonstrate that CEOs are awarded the chair position as a normal part of the succession process; successful CEOs later become CEO/Chair.

10. Researchers generally agree that discretionary accruals capture financial reporting quality though there are debates on which is the most effective measure of discretionary accruals. In our robustness checks, we adopt several discretionary accruals measures as well as other prevailing earnings management measures, our conclusions generally remain the same (see Jones 1991; Jones, Krishnan, and Melendrez 2008; Dechow and Dichev 2002; Kothari et al. 2005; Dechow et al. 1995; Cheng et al. 2012).

11. The Dodd-Frank Wall Street Reform and Consumer Protection Act was signed into law by President Barack Obama on July 21,2010. While the law emerged from a Senate committee session with a clawback provision on March 15, 2010, it seems unlikely that firms adopted clawback provisions in response prior to the ending of our sample period.

12. Execucomp includes annual compensation data from proxy statements for the five highest paid executives for firms in the S\&P 500, the S\&P MidCap 400, and the S\&P SmallCap 600. This limits the potential sample to the S\&P 1500 .

13. For instance, Dehaan et al. (2011) analyze 228 non-financial S\&P 1500 firms that adopt clawback provisions from 2006 to 2009, while Chan et al. (2011) study 343 non-financial Russell 3000 firms that adopt clawback provisions from 2005 to 2009 .

14. In addition to performance-matched discretionary accruals, we also use various discretionary accruals prevailing in current literature to validate our results (i.e., Cheng et al. 2012; Dechow and Dichev 2002). Our conclusions remain the same.

15. We are grateful to John Graham for providing his estimates of marginal tax rates.

16. We use the standard deviation of cash flows from operations to assets (SDCFOTA), the standard deviation of sales to assets (SDSALETA), and an indicator if the net income before extraordinary items is negative (LOSS) as in Biddle et al. (2009). In addition, we include research and development expenditures to sales (RDS) and financial leverage (TDTA) as in Barton (2001). Firms with greater growth opportunities and more highly levered are more likely to manage earnings. Lastly, we control for the dividend payout rate (DVPOR) and level of free cash flow to assets (OANCFTA). Many of these additional variables are collinear with the variables listed above. However, our results are qualitatively similar when included in the models.

17. We report average marginal effects rather than marginal effects at the mean because sample means may reflect nonsensical or nonexistent observations, such as in the case of binary variables (Long, 1997). We 
report discrete changes for dummy variables which measure the change in the probability as the indicator variable goes from 0 to 1 , holding all other variables at their mean.

18. Our results are robust to using a 3 year period $(t=-1$ to +1$)$ and requiring all firms to be in the sample for the full 5 year period $(t=-2$ to +2$)$ or full 3 year period $(t=-1$ to +1$)$.

19. These variables are collinear with the firm-fixed effect for high board independence and high discretionary accrual firms. (See Low (2009) for a similar experimental design).

\section{REFERENCES}

Aboody, D. \& Kasznik, R. (2000). CEO stock option awards and the timing of corporate voluntary disclosures. Journal of Accounting and Economics, 29, 73-100.

Adams, R. B. \& Ferreira, D. (2007). A theory of friendly boards. Journal of Finance, 62, (1), 217-250.

Adams, R, B., Hermalin, B. E. \& Weisbach, M. S. (2010). The role of boards of directors in corporate governance: a conceptual framework and survey. Journal of Economic Literature, 48, (1), 58107.

Addy, N., Chu, X.Y. \& Yoder, T.R. (2014). Voluntary adoption of clawback provisions, corporate governance \& interlock effects. Journal of Accounting \& Public Policy, 33, (2), 167-189.

Ahmed, A.S. \& Duellman, S. (2007). Accounting conservatism and board of director characteristics: an empirical analysis. Journal of Accounting and Economics, 43, (2-3), 411-437.

Angrist J.D. \& Pischke, J.S. (2008) Mostly harmless econometrics: an empiricist's companion. Princeton University Press, Princeton, NJ.

Armstrong C., Wayne, G. \& Weber, J. (2010). The role of information and financial reporting in corporate governance and debt contracting, Journal of Accounting \& Economics, 50, 179-234.

Bainbridge, S.M. (2011). Dodd-Frank: Quack federal corporate governance round II. Research Paper No.10-12. University of California. Retrieved from: $\underline{\text { http://ssrn.com/abstract }=1673575}$

Baker, T., Collins, D. \& Reitenga, A. (2003). Stock option compensation and earnings management incentives. Journal of Accounting, Auditing, and Finance, 18, 557-582.

Baltagi, B.H. (2008). Econometric Analysis of Panel Data, 4th edition. United Kingdom: Wiley, Blackwell.

Bargeron, L., Lehn, K. \& Zutter, C. (2010). Sarbanes-Oxley and corporate risk-taking. Journal of Accounting and Economics, 49, 34-52.

Bartov, E. \& Mohanram, P. (2004). Private information, earnings manipulations and executive stock option exercises. The Accounting Review, 79, (4), 889-920.

Bebchuk, L.A. \& Fried, J.M. (2003). Executive compensation as an agency problem. Journal of Economic Perspectives, 17, (3), 71-92.

Bebchuk, L. A. \& Fried, J.M. (2005). Pay without performance: overview of the issues. Journal of Corporation Law, 30, (4), 647-673.

Bergstresser, D. \& Philippon, T. (2006). CEO incentives and earnings management. Journal of Financial Economics, 80, 511-529.

Bhagat, S. \& Black, B.S. (2002). The non-correlation between board independence and long-term firm performance. The Journal of Corporation Law, 27, 231-273.

Bhagat, S. \& Romano, R. (2009). Reforming executive compensation: focusing and committing to the long-term. Working paper. Yale Law School. Retrieved from http://digitalcommons.law.yale.edu/fss papers/1921

Booth, J. R., Cornett, M.M. \& Tehranian, H. (2002). Boards of directors, ownership, and regulation. Journal of Banking \& Finance, 26,(10), 1973-1996.

Brickley, J. A., Coles, J.F. \&Terry, R.L. (1994). Outside directors and the adoptions of poison pills. Journal of Financial Economics, 35, 371-390.

Brown, A., Friday, P.D. \& Guler. (2011). Economic determinants of the voluntary adoption of clawback provisions in executive compensation contracts. Working paper. Baruch College. 
Burks, J. J. (2010). Disciplinary measures in response to restatements after Sarbanes-Oxley. Journal of Accounting and Public Policy, 29, 195-225.

Burns, N. \& Kedia, S. (2006). The impact of performance-based compensation on misreporting. Journal of Financial Economics, 79, 35-67.

Bushman, R., Chen, Q., Engel, E., \& Smith, A. (2004). Financial accounting information, organizational complexity and corporate governance systems. Journal of Accounting and Economics, 37, 167201.

Bushman, R. M. \& Smith, A. J. (2001). Financial accounting information and corporate governance. Journal of Accounting and Economics, 32,(1-3), 237-333.

Chan, L., Chen, K.C., Chen, T.Y. \& Yu, Y. (2012). Journal of Accounting and Economics, 54, (2-3), $180-$ 196.

Byrd, J. J. \& Hickman, K.A. (1992). Do outside directors monitor managers? Journal of Financial Economics, 32, 195-221.

Collins, D., Masli, A. D. I., Reitenga, A. L., \& Sanchez, J. M. (2009). Earnings restatements, the Sarbanes-Oxley Act, and the disciplining of chief financial officers. Journal of Accounting, Auditing \& Finance, 24,(1), 1-34.

Core, J., Holthausen, R. \& Larcker, D. (1999). Corporate governance, chief executive officer compensation, and firm performance. Journal of Financial Economics, 51, 371-406.

Cotter, J., Shivdasani, A. \& Zenner, M. (1997). Do independent directors enhance target shareholder wealth during tender offers? Journal of Financial Economics, 43, 195-218.

Davidson, R. \& MacKinnon, J.G. (1993). Estimation and inference in econometrics, Oxford University Press, New York, NY.

Dehaan, E., Hodge, F. \& Shevlin, T. (2011). Does voluntary adoption of a clawback provision improve financial reporting quality? Working paper, University of Washington Retrieved from: http://www.bus.miami.edu/_assets/files/faculty-and-research/conferences-and-seminars/financeseminars/Shevlin\%20Paper.pdf

Denis, D. (2012). Mandatory clawback provisions, information disclosure, and the regulation of securities markets. Journal of Accounting and Economics, 54, (2-3), 197-200.

Dikolli, S. S. (2001). Agent employment horizons and contracting demand for forward-looking performance measures. Journal of Accounting Research, 39, (3), 481-494.

Doyle, J., Ge, W.L. \& McVay, S. (2007). Determinants of weaknesses in internal control over financial reporting. Journal of Accounting and Economics, (44), 193-223.

Duchin, R., Matsusaka, J. G. \& Oguzhan, O. (2010). When are outside directors effective? Journal of Financial Economics, 96, (2), 195-214.

Drymiotes, G. (2007). The monitoring role of insiders. Journal of Accounting and Economics, 44 (3), 359-377.

Dvorak, P. \& Ng. S. (2006). Check, please: reclaiming pay from executives is tough to do. The Wall Street Journal Nov. 20, 2006, p. A1.

Dyck, A., Morse, A. \& Zingales, L. (2010). Who blows the whistle on corporate fraud? The Journal of Finance, 65, (6), 2213-2253.

Efendi, J., Srivastava, A. \& Swanson, E. (2007). Why do corporate managers misstate financial statements? the role of option compensation and other factors. Journal of Financial Economics, $85,667-708$.

Eisenberg, T., Sundgren, S. \& Wells, M. (1998). Larger board size and decreasing firm value in small firms. Journal of Financial Economics, 48, 35-54.

Fama, E. F. \& Jensen, M.C. (1983). Agency problems and residual claims. Journal of Law and Economics, 26, 327-49.

Frederic W. Cook \& Co. (2011). Executive compensation year in review: looking back on 2010 and implications for 2011. (2011, March 23). Retrieved from:

http://www.fwcook.com/alert letters/03-23-

90 Journal of Accounting and Finance Vol. 18(1) 2018 
11_Executive_Compensation_Year_In_Review_Looking_Back_on_2010_and_Implications_for 2011.pdf

Fried, J. \& Shilon, N. (2011). Excess-pay clawbacks. Journal of Corporation Law, 26, 722-751.

Gaver, J., Gaver, K. \& Austin, J. (1995). Additional evidence on bonus plans and income management. Journal of Accounting and Economics, 19, 3-28.

Glater, J. D. (2005). Sorry, I'm keeping the bonus anyway. New York Times, March 13, 2005. Retrieved from: http://query.nytimes.com/gst/fullpage.html?res=9A00E4DC143CF930A25750C0A9639C8B63

Guidry, F., Leone, A.J. \& Rock, S. (1999). Earnings-based bonus plans and earnings management by business-unit managers. Journal of Accounting and Economics, 26, 113-142.

Haugen, R. A. \& Senbet, L. W. (1981). Resolving agency problems of external capital through options. Journal of Finance, 36, 629-647.

Healy, P. (1985). The effect of bonus schemes on accounting decisions. Journal of Accounting and Economics, 7, 85-107.

Healy, P., Kang, S. \& Palepu, K. G. (1987). The effect of accounting procedure changes on CEO's cash salary and bonus compensation. Journal of Accounting and Economics, 9,(1), 7-34.

Hermalin, B.E. \& Weisbach, M.S. (2003). Boards of directors as an endogenously determined institution: a survey of the economic literature. Economic Policy Review, 9, (1), 7-26.

Hoitash, R., Hoitash, U. \& Bedard, J. C. (2009). Evidence from the U.S. on the effect of auditor involvement in assessing internal control over financial reporting. International Journal of Auditing, 13, (2), 105-125.

Hoitash, U., Hoitash, R. \& Bedard, J. C. (2009). Corporate governance and internal control over financial reporting: a comparison of regulatory regimes. The Accounting Review, 84, (3), 839-867.

Holthausen, R., Larcker, D. \& Sloan, R. (1995). Annual bonus schemes and the manipulation of earnings. Journal of Accounting and Economics, 19, 29-74.

Jensen, M. (1993). The modern industrial revolution, exit, and the failure of internal control systems, Journal of Finance, 48, 831-880.

Jensen, M. \& Meckling, W. H. (1976). Theory of the firm: managerial behavior, agency costs and ownership structure. Journal of Financial Economics, 3, (4), 305-360.

Johnson, S., Harley, E. R. \& Tian, Y.S. (2009). Managerial incentives and corporate fraud: the sources of incentives matter," Review of Finance, 13, 115-145.

Kedia, S. \& Philippon, T. (2010). The economics of fraudulent accounting. Review of Financial Studies, 23, 939-961.

Klein, A. (1998). Firm performance and board committee structure. Journal of Law and Economics, 41,(1), 275-303.

Klein, A. (2002). Audit committee, board of director characteristic, and earnings management. Journal of Accounting and Economics, 33, 375-400.

Kothari, S.P., Leone, L.J. \& Wasley, C.E. (2005). Performance matched discretionary accrual measures. Journal of Accounting \& Economics, 39, (1), 163-197.

La Porta, R., Lopez-de-Silanes, F. \& Shleifer, A. (2006). What works in securities laws? Journal of Finance, 61, 1-33.

Lambert, R. A. (2001). Contracting theory and accounting. Journal of Accounting \& Economics, 32, (13), 3-87.

Laux, V. (2008). Board independence and CEO turnover. Journal of Accounting Research, 46, (1), 13771.

Laux, C. \& Laux, V. (2009). Board committees, CEO compensation, and earnings management. Accounting Review, 84, (3), 869-891.

Lie, E. (2005). On the timing of CEO stock option awards. Management Science, 51, 802-812.

Linck, J. S., Netter, J.M. \&Yang, T. (2008). The determinants of board structure. Journal of Financial Economics, 87, 308-328. 
McAnally, M. L., Srivastava, A. \& Weaver, C.D. (2008) Executive stock options, missed earnings targets, and earnings management. Accounting Review, 83, (1), 185-216.

Myers, S.C. (1977). Determinants of corporate borrowing. Journal of Financial Economics, 5, 147-175.

Nike, Inc. Policy for Recoupment of Incentive Compensation - NIKE, Inc.(Jul 20, 2010) Retrieved from: http://contracts.corporate.findlaw.com/compensation/incentive/10734.html

Nguyen, B.D. \& Nielsen K.M. (2010). The value of independent directors: evidence from sudden death. Journal of Financial Economics, 98, (3), 550-567.

Nguyen B.D. \& Nielsen, K. (2010). What death can tell: are top executives paid for their contributions to firm value? Social Science Research Network Working Papers Series, No.1695366. Rochester, NY: Social Science Electronic Publishing.

Raheja, C. G. (2005). Determinants of board size and composition: a theory of corporate boards, Journal of Financial and Quantitative Analysis, 40, (2), 283-306.

Rosenstein, S. \& Wyatt, J.G. (1990). Outside directors, board independence, and shareholder wealth. Journal of Financial Economics, 26, 175-192.

Salehi, N.H. \& Marino, E. A. (2008). Section 304 of SOX: new tool for disgorgement? New York Law Journal 239.

Scheer, D., Westbrook, J \& Gallu, J. (2009). SEC demands Ex-CSK chief Forfeit pay in landmark case (Updated1). Bloomberg. (2009, July 22). Retrieved from: http://www.bloomberg.com/apps/news?pid=newsarchive\&sid=aqI28XZcPPHw

Song, C.J., Thomas, W.B.\& Li, H. (2010). Value relevance of FAS 157 fair value hierarchy information and the impact of corporate governance mechanisms. The Accounting Review, 85, 4, 1375-1410.

Spence, M. (1973). Job Market Signaling. The Quarterly Journal of Economics, 87, (3): 355-374.

Towers, W. (2010). Mandated clawbacks will create new tensions between executives and boards. Insiders. Retrieved from: http://www.towerswatson.com/assets/pdf/2952/Oct10Ins-ClawbacksFIN3.pdf

Turner, L. E. \& Weirich, T.R. (2006). A closer look at financial statement restatements: analyzing the reasons behind the trend. The CPA Journal, 76, 12-23.

Wang, X. (2010). Increased disclosure requirements and corporate governance decisions: evidence from Chief Financial Officers in the pre- and post-Sarbanes Oxley periods. Journal of Accounting Research, 48, 885-920.

Watts, R. L. \& Zimmerman, J.L. (1986). Positive accounting theory. New Jersey: Prentice-Hall, Inc.

Xie, B., Davidson, W.N. \& DaDalt, P.J. (2003). Earnings management and corporate governance: the role of the board and the audit committee. Journal of Corporate Finance, 9, (3), 295-316.

Yermack, D. (1996). Higher market valuation of companies a small board of directors. Journal of Financial Economics, 40, 185-202.

Yermack, D. (1997). Good timing: CEO stock option awards and company news announcements. Journal of Finance, 52, 449-476.

Zang, A. Y. (2012). Evidence on the trade-off between real activities manipulation and accrual-based earnings management. The Accounting Review, 87,(2),675-703. 


\section{APPENDIX A}

\begin{tabular}{|c|c|}
\hline \multicolumn{2}{|r|}{ DESCRIBES THE CONSTRUCTION OF THE VARIABLES AND DATA SOURCES } \\
\hline CLAW & $\begin{array}{l}\text { An indicator variable equal to one if the firm has adopted a clawback provision, zero otherwise. } \\
\text { Data Source: Corporate Library database and Proxy Statements }\end{array}$ \\
\hline DA & $\begin{array}{l}\text { Performance-matched discretionary accruals (Kothari et al. 2005), section } 3.2 .1 \text { provides details. } \\
\text { Data Source: Compustat }\end{array}$ \\
\hline PIND & $\begin{array}{l}\text { Proportion of independent directors on the board. } \\
\text { Data Source: RiskMetrics and Equilar }\end{array}$ \\
\hline BDSIZE & $\begin{array}{l}\text { Number of directors serving on the board. } \\
\text { Data Source: RiskMetrics and Equilar }\end{array}$ \\
\hline DUALITY & $\begin{array}{l}\text { An indicator variable equals to one if the CEO is also the chairman of the board, zero otherwise. } \\
\text { Data Source: RiskMetrics and Equilar }\end{array}$ \\
\hline TENURE & $\begin{array}{l}\text { Time the CEO has served in the position of CEO. } \\
\text { Data Source: Execucomp }\end{array}$ \\
\hline PBONUS & $\begin{array}{l}\text { Proportion of bonus-based compensation to total annual compensation. } \\
\text { Data Source: Execucomp }\end{array}$ \\
\hline POPTION & $\begin{array}{l}\text { Proportion of option-based compensation to total annual compensation. } \\
\text { Data Source: Execucomp }\end{array}$ \\
\hline MKTSHARE & $\begin{array}{l}\text { The percentage of the company's sales to the total sales of its industry at the beginning of year } \mathrm{t} \text {, } \\
\text { where industry is defined based on 3-digit SIC codes. } \\
\text { Data Source: Compustat }\end{array}$ \\
\hline ZSCORE & $\begin{array}{l}\text { Altman's Z-score. } \\
\text { Data Source: Compustat }\end{array}$ \\
\hline INSTOWN & $\begin{array}{l}\text { Institutional ownership percentage. } \\
\text { Data Source: Thompson } 13 \mathrm{~F}\end{array}$ \\
\hline MTR & $\begin{array}{l}\text { Marginal tax rates. } \\
\text { Data Source: https://faculty.fuqua.duke.edu/ jgraham/taxform.html }\end{array}$ \\
\hline MISSMTR & $\begin{array}{l}\text { An indicator variable equal to one if MTR is missing, zero otherwise. } \\
\text { Data Source: https://faculty.fuqua.duke.edu/ jgraham/taxform.html }\end{array}$ \\
\hline BIG8 & $\begin{array}{l}\text { Indicator equal to } 1 \text { if auditor from Big } 8 . \\
\text { Data Source: Compustat }\end{array}$ \\
\hline ATENURE & $\begin{array}{l}\text { The tenure of the auditing firm. } \\
\text { Data Source: Compustat }\end{array}$ \\
\hline SOX & Indicator equal to 1 if the observation is from 2003 (i.e. after Sarbanes-Oxley) or later. \\
\hline NOAS & $\begin{array}{l}\text { Indicator variable that equals one if the net operating assets (i.e., shareholders' equity less cash } \\
\text { and marketable securities and plus total debt) at the beginning of the year divided by lagged sales } \\
\text { is above the median of the corresponding industry-year, and zero otherwise. } \\
\text { Data Source: Compustat }\end{array}$ \\
\hline CYCLE & $\begin{array}{l}\text { The days receivable plus the days inventory less the days payable at the beginning of the year. } \\
\text { Data Source: Compustat }\end{array}$ \\
\hline LNTA & $\begin{array}{l}\text { Log of total assets. } \\
\text { Data Source: Compustat }\end{array}$ \\
\hline ROA & $\begin{array}{l}\text { Return on assets. } \\
\text { Data Source: Compustat }\end{array}$ \\
\hline Q & $\begin{array}{l}\text { Tobin's Q: Market value of assets over book value of assets. } \\
\text { Data Source: Compustat }\end{array}$ \\
\hline PFFIND49 & $\begin{array}{l}\text { Proportion of firms that have adopted a clawback provision in the same Fama-French } 49 \text { industry } \\
\text { segment. } \\
\text { Data Source: Corporate Library database and Proxy Statements }\end{array}$ \\
\hline
\end{tabular}

